DOI: $10.5800 / G T-2020-11-3-0494$

\title{
MODELS OF THE MACROSEISMIC FIELD EARTHQUAKES AND THEIR INFLUENCE ON SEISMIC HAZARD ASSESSMENT VALUES FOR CENTRAL ASIA
}

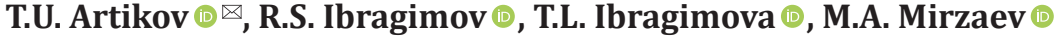

Mavlyanov Institute of Seismology, Uzbekistan Academy of Sciences, 3 Zulfiyakhonum St, Tashkent 100128, Uzbekistan

\begin{abstract}
Seismic intensity assessment in points of a macroseismic scale plays an important role for researching the seismic history of areas characterized by active seismicity, as well as for construction (and updating) of seismic zoning maps in various scales. Macroseismic scale points are generally referred to in construction standards applied in the majority of post-Soviet states. In our study aimed to model the macroseismic field of earthquakes, a large volume of macroseismic data on Central Asia was analyzed, and coefficients used in Blake-Shebalin and Covesligeti equations were aligned. This article presents a generalized dependence model of macroseismic intensity attenuation with distance. The model takes into account seismic load features determined by various depths of earthquakes. The ratios of small and big axes of the ellipse, that approximates real isoseists, are estimated with respect to seismic scale points, earthquake depths and magnitudes. The East Uzbekistan area is studied as an example to investigate whether seismic hazard assessment values may differ depending on a chosen law of seismic influence intensity attenuation with distance.
\end{abstract}

KEYWORDS: macroseismic intensity; isoseists; law of macroseismic intensity attenuation; seismic source; seismic hazard; seismic zoning

\section{RESEARCH ARTICLE}

Correspondence: Turdali U. Artikov, artikovtu@mail.ru
Received: May 6, 2019

Revised: April 30, 2020

Accepted: May 14, 2020

FOR CITATION: Artikov T.U., Ibragimov R.S., Ibragimova T.L., Mirzaev M.A., 2020. Models of the macroseismic field earthquakes and their influence on seismic hazard assessment values for Central Asia. Geodynamics \& Tectonophysics 11 (3), 606-623. doi:10.5800/ GT-2020-11-3-0494 


\title{
МОДЕЛИ МАКРОСЕЙСМИЧЕСКОГО ПОЛЯ ЗЕМЛЕТРЯСЕНИЙ ЦЕНТРАЛЬНОЙ АЗИИ И ИХ ВЛИЯНИЕ НА РЕЗУЛЬТИРУЮЩИЕ ОЦЕНКИ СЕЙСМИЧЕСКОЙ ОПАСНОСТИ
}

\author{
Т.У. Артиков, Р.С. Ибрагимов, Т.Л. Ибрагимова, М.А. Мирзаев
}

Институт сейсмологии им. Г.А. Мавлянова АН РУз, 100128, Ташкент, ул. Зульфияхонум, 3, Узбекистан

АНнОТАЦИЯ. Оценка интенсивности сейсмических воздействий в баллах макросейсмической шкалы играет важную роль как для исследования исторической сейсмичности сейсмоактивных территорий, так и для составления и уточнения разномасштабных карт сейсмического районирования, поскольку строительные нормы большинства стран постсоветского пространства опираются именно на эту характеристику сейсмических воздействий. Целью исследования является построение адекватной модели макросейсмического поля землетрясений Центральной Азии. В статье на основе большого объема макросейсмических данных, наряду с уточнением коэффициентов в уравнениях типа Блейка - Шебалина и Ковеслигети для территории Центральной Азии, предложена обобщенная зависимость затухания макросейсмической интенсивности с расстоянием с учетом особенностей сейсмических воздействий, обусловленных различной глубиной происходящих землетрясений. Получены соотношения между малой и большой осями эллипса, аппроксимирующего реальные изосейсты, в зависимости от балльности сотрясения, глубины и магнитуды землетрясения. На примере территории Восточного Узбекистана исследован вопрос о влиянии выбора закона затухания интенсивности сейсмических воздействий с расстоянием на результирующие оценки сейсмической опасности.

КЛЮЧЕВЫЕ СЛОВА: макросейсмическая интенсивность; изосейсты; закон затухания макросейсмической интенсивности; очаг землетрясения; сейсмическая опасность; сейсмическое районирование

\section{1. ВВЕДЕНИЕ}

Несмотря на очевидные преимущества оценок сейсмической опасности, представляемых в инженерных показателях колебаний грунта при землетрясениях (смещения, скорости, ускорения и спектральные амплитуды этих параметров), оценки интенсивности сейсмических воздействий в баллах макросейсмической шкалы играют важную роль как для исследования исторической сейсмичности сейсмоактивных территорий [New Catalog..., 1977; Shebalin, 1968; Tatevosyan, 2013; и др.], так и для составления и уточнения разномасштабных карт сейсмического районирования, поскольку действующие строительные нормы большинства стран постсоветского пространства существенно опираются именно на эту характеристику сейсмических воздействий [Ulomov et al., 2016; Artikov et al., 2018; и др.].

К настоящему времени для всей территории Центральной Азии и различных ее регионов предложен ряд уравнений макросейсмического поля, построенных на основе анализа макросейсмических данных последствий ощутимых и сильных землетрясений [New Catalog..., 1977; Artikov et al., 2012; Seiduzova, 1990; Sadykov, 2004; Dzhanuzakov et al., 1980; Mirzoev, Dzhuraev, 1985]. Сводка уравнений макросейсмического поля для семи крупных квазиоднородных в сейсмологическом отношении провинций Центральной Азии содержится в работе C.C. Сейдузовой [Seiduzova, 1990], где для каждой из них приведены законы затухания интенсивности сейсмических воздействий с расстоянием различного типа, полученные как с определением макросейсмического гипоцентра землетрясения, так и без такого определения. Наиболее распространенными типами зависимостей затухания макросейсмической балльности $I$ с ростом гипоцентрального расстояния $R$ от землетрясения с магнитудой М являются зависимости вида Блейка - Шебалина [Shebalin, 1968, 1972] $I=a M-b \lg R+c$ и Ковеслигети [Kovesligethy, 1907] $I=a \mathrm{M}-b \lg R-d R+c$ ввиду их простоты и устойчивости решения обратной задачи по нахождению входящих в них коэффициентов. Эти формулы имеют достаточно простой физический смысл. В первой полагается, что уменьшение балльности с удалением от источника происходит за счет расхождения энергии сейсмических волн, во второй также учитывается эффект поглощения средой части выделившейся сейсмической энергии [Riznichenko, 1985]. Вместе с тем каждая из этих зависимостей в недостаточной степени учитывает особенности проявления макросейсмических воздействий, вызванных различной глубиной заложения очага землетрясения. В частности, эмпирический факт, состоящий в более быстром затухании интенсивности сейсмических воздействий с удалением от источника для землетрясений с малой глубиной очага, по сравнению с землетрясениями, происходящими на больших глубинах, не находит отражения в формулах типа Блейка - Шебалина и Ковеслигети, в которых коэффициент $b$, характеризующий уменьшение балльности с расстоянием, является величиной постоянной.

В статье на основе большого объема макросейсмических данных, наряду с уточнением коэффициентов в уравнениях типа Блейка - Шебалина и Ковеслигети для территории Центральной Азии, обсуждается обобщенная зависимость затухания макросейсмической интенсивности от расстояния с учетом особенностей сейсмических воздействий, обусловленных различной глубиной происходящих землетрясений, а также 
исследуются соотношения между малой и большой осями эллипса, аппроксимирующего реальные изосейсты, в зависимости от балльности сотрясения, глубины и магнитуды землетрясения. На примере территории Восточного Узбекистана изучен вопрос о влиянии выбора закона затухания интенсивности сейсмических воздействий с расстоянием на результирующие оценки сейсмической опасности.

\section{2. ИСХОДНЫЕ МАКРОСЕЙСМИЧЕСКИЕ ДАННЫЕ И МЕТОДИКА ИХ АНАЛИЗА}

Информационной основой проведенного исследования являлась созданная в Институте сейсмологии АН РУз база макросейсмических данных, включающая схемы изосейст сильных землетрясений Центральной Азии и таблицы «пункты - баллы» изучаемых землетрясений. Электронная версия базы макросейсмических данных начала формироваться с конца 80 - начала 90-х г. прошлого столетия, когда усилиями специалистов из сейсмологических центров республик Средней
Азии были унифицированы макросейсмические материалы по каждой территории для построения новой карты сейсмического районирования среднеазиатской части Советского Союза. Эта карта должна была заменить карту ОСР-78. Существующая база макросейсмических данных по территории Центральной Азии была дополнена схемами изосейст сильных землетрясений, произошедших на территории Узбекистана и в приграничных с ним областях за последние 25 лет: Избаскентского (Кочкор-Атинское) 15 мая 1992 г., M=5.9 [Dzhanuzakov et al., 1997]; Канского 19 июля 2011 г., M=6.2 [Ziyaudinov et al., 2012]; Туябугузского 24 мая 2013 г., $M=5.6$ [Artikov et al., 2014]; Марджанбулакского 26 мая 2013 г., $M=6.1$ [Usmanova et al., 2015]; Бахмальского 29 сентября 2017 г., $M=5.1$ [Ismailov et al., 2018], и др. В итоге общее число землетрясений, для которых имелись сведения о макросейсмическом обследовании, составило 171 событие. На рис. 1 представлена карта эпицентров сильных землетрясений территории Центральной Азии, по которым имелись макросейсмические данные. Здесь же,

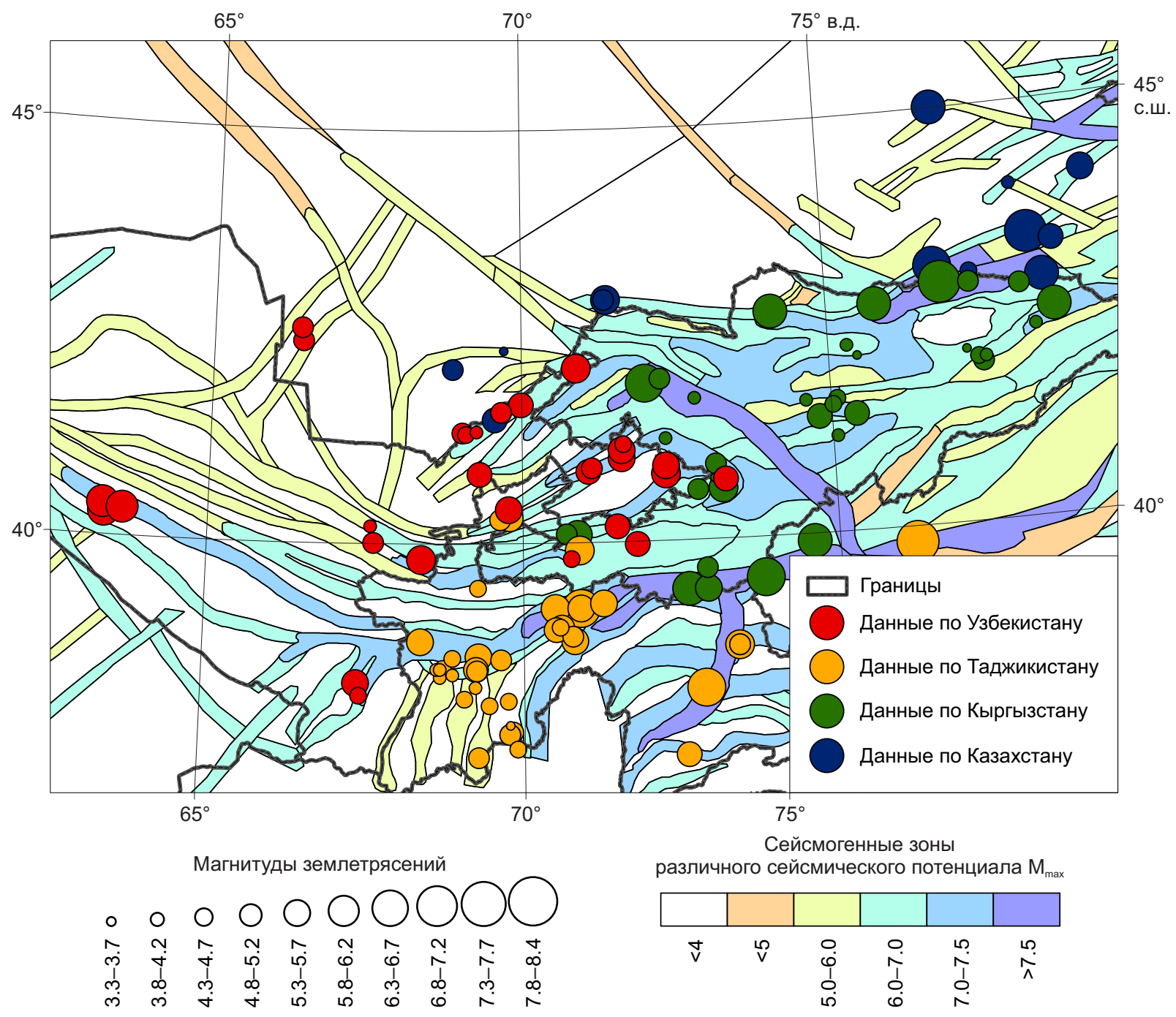

Рис. 1. Карта эпицентров землетрясений территории Центральной Азии, для которых имелись данные по макросейсмическому обследованию.

Fig. 1. Central Asia map showing earthquake sources with available macroseismic data. 
на этой карте, приведены основные сейсмогенерирующие зоны исследуемого региона. Электронная версия схемы сейсмогенерирующих зон Центрально-Азиатского региона была создана в рамках международного проекта ЕМСА (модель землетрясений Центральной Азии) [Danciu, Giardini, 2015] на базе единой карты сейсмогенерирующих зон Центральной Азии образца 1995 г. [Chediya et al., 1995].

На рис. 2 приведена сводная карта изосейст сильных землетрясений территории Узбекистана и прилегающих к нему территорий, где показаны изосейсты с балльностью I $\geq 6$ по шкале MSK-64. Параметры землетрясений, изосейсты которых изображены на рис. 2 , сведены в табл. 1.

В качестве основной характеристики для классификации землетрясений по величине в региональном каталоге Узбекистана длительное время использовался энергетический класс землетрясений $K$, введенный в работах Т.Г. Раутиан [Rautian, 1960], который связан с высвобожденной сейсмической энергией зависимостью $K=\lg E$ (дж). Для различных землетрясений, содержащихся в каталоге, кроме энергетического класса землетрясения $K$, использовались различные типы магнитуд: $M_{S}, m_{b}, M_{L H^{\prime}}$ поэтому в целях гомогенизации каталога для последующих построений был проведен пересчет исходных энергетических характеристик всех сейсмических событий к единой магнитуде. Поскольку в зависимости затухания интенсивности сейсмических воздействий с расстоянием Н.В. Шебалина [Shebalin, 1968, 1972], полученной по большому массиву макросейсмических данных из различных регионов земного шара, с которой впоследствии сопоставлялись полученные в данной работе зависимости, рассматривается магнитуда $M_{S}$, определяемая по поверхностным волнам, был проведен пересчет каждого землетрясения из каталога к этому типу магнитуды. Уравнения связи между энергетическим классом землетрясения и различными типами магнитуд для исследуемого района приводятся в работах [Rautian et al., 2007; Mukambaev, Mikhailova, 2014; и др.]. В данном исследовании использовались следующие уравнения ортогональной регрессии, связывающие энергетический класс землетрясения $K$ и магнитуды $M_{S}, m_{b}, M_{L H}$, заимствованные из работы А.С. Мукамбаева и Н.Н. Михайловой [Mukambaev, Mikhailova, 2014]:

$$
M_{L H}=0.47 K-1.15
$$

Таблица 1. Параметры землетрясений, схемы изосейст которых представлены на рис. 2

Table 1. Parameters of earthquakes (see the isoseist schemes in Fig. 2)

\begin{tabular}{|c|c|c|c|c|c|}
\hline № & $\begin{array}{l}\text { Название } \\
\text { землетрясения }\end{array}$ & Дата & $\mathrm{H}$ & $\mathrm{M}_{\mathrm{s}}$ & $I_{0}$ \\
\hline 1 & Кокандское & 1823 & 12 & 6.2 & $8-9$ \\
\hline 2 & Ошское & 14.09.1883 & 12 & 5.5 & $7-8$ \\
\hline 3 & Уратюбинское I & 17.09.1897 & 25 & 6.6 & 8 \\
\hline 4 & Уратюбинское II & 17.09.1897 & 45 & 6.7 & 7 \\
\hline 5 & Андижанское & 16.12.1902 & 9 & 6.4 & 9 \\
\hline 6 & Каратагское & 21.10.1907 & 24 & 7.3 & 9 \\
\hline 7 & Байсунское & 05.12.1935 & 18 & 6.2 & 8 \\
\hline 8 & Пскемское & 18.12.1937 & 25 & 6.5 & $7-8$ \\
\hline 9 & Яртепинское & 18.01.1942 & 21 & 5.9 & 7 \\
\hline 10 & Чаткальское & 02.09.1946 & 30 & 7.5 & $9-10$ \\
\hline 11 & Бурчмуллинское & 24.10.1959 & 13 & 5.7 & $7-8$ \\
\hline 12 & Маркайское & 03.08.1962 & 18 & 5.4 & $7-8$ \\
\hline 13 & Тергаучинское & 19.10.1963 & 8 & 4.7 & $6-7$ \\
\hline 14 & Коштепинское & 17.03.1965 & 12 & 5.5 & 7 \\
\hline 15 & Ташкентское & 25.04.1966 & 8 & 5.1 & $7-8$ \\
\hline 16 & Балыкчинское & 30.04 .1966 & 20 & 5.2 & $6-7$ \\
\hline 17 & $\begin{array}{l}\text { Ташкентское } \\
\text { (афтершок) }\end{array}$ & 09.05.1966 & 8 & 4.2 & 7 \\
\hline 18 & Букинское & 13.03.1967 & 20 & 4.3 & 6 \\
\hline 19 & Супетауское & 18.05.1967 & 25 & 4.6 & 7 \\
\hline 20 & Чимкентское & 29.10 .1967 & 15 & 4.1 & 6 \\
\hline 21 & Кызылкумское I & 13.03.1968 & 25 & 5.1 & 7 \\
\hline 22 & Кызылкумское II & 14.03 .1968 & 17 & 5.1 & 7 \\
\hline 23 & Байсунское & 08.08.1968 & 15 & 4.8 & $6-7$ \\
\hline 24 & Булакбашинское & 13.05.1969 & 7 & 4.5 & 6 \\
\hline 25 & Пскентское & 19.01.1970 & 25 & 4.7 & 7 \\
\hline 26 & Абайское & 08.02 .1971 & 10 & 4.2 & 6 \\
\hline 27 & Джамбульское & 10.05 .1971 & 20 & 5.7 & 7 \\
\hline
\end{tabular}

\begin{tabular}{|c|c|}
\hline № & $\begin{array}{l}\text { Название } \\
\text { землетрясения }\end{array}$ \\
\hline 28 & Чаткальское \\
\hline 29 & Лянгарское \\
\hline 30 & Ленинабадское \\
\hline 31 & Кадамжайское \\
\hline 32 & Куршабское \\
\hline 33 & Галляаральское \\
\hline 34 & Маркансуйское \\
\hline 35 & Газлийское I \\
\hline 36 & Газлийское II \\
\hline 37 & Исфара-Баткенское \\
\hline 38 & Шахимарданское \\
\hline 39 & Таваксайское \\
\hline 40 & Газлийское (афтершок) \\
\hline 41 & Дараут-Курганское \\
\hline 42 & Назарбекское \\
\hline 43 & Назарбекское (афтершок) \\
\hline 44 & Чимионское \\
\hline 45 & Джизакское \\
\hline 46 & Папское \\
\hline 47 & Газлийское \\
\hline 48 & Кайраккумское \\
\hline 49 & Папское \\
\hline 50 & $\begin{array}{l}\text { Избаскентское } \\
\text { (Кочкор-Атинское) }\end{array}$ \\
\hline 51 & Канское \\
\hline 52 & Туябугузское \\
\hline 53 & Марджанбулакское \\
\hline 54 & Бахмальское \\
\hline
\end{tabular}

\begin{tabular}{cccc} 
Дата & $\mathrm{H}$ & $\mathrm{M}_{\mathrm{s}}$ & $\mathrm{I}_{\mathrm{o}}$ \\
\hline 28.10 .1971 & 17 & 5.6 & $6-7$ \\
18.11 .1971 & 20 & 5.3 & 7 \\
17.03 .1972 & 20 & 5.2 & $6-7$ \\
22.01 .1974 & 24 & 5.0 & 6 \\
20.02 .1974 & 15 & 5.4 & $6-7$ \\
24.02 .1974 & 15 & 4.2 & 6 \\
11.08 .1974 & 18 & 7.3 & $7-8$ \\
08.04 .1976 & 30 & 7.0 & $8-9$ \\
17.05 .1976 & 30 & 7.3 & $9-10$ \\
31.01 .1977 & 20 & 6.1 & $7-8$ \\
03.06 .1977 & $10-15$ & 5.2 & $6-7$ \\
06.12 .1977 & 15 & 4.9 & 7 \\
04.06 .1978 & 15 & 6.0 & 7 \\
01.11 .1978 & 20 & 6.8 & $7-8$ \\
11.12 .1980 & 10 & 5.3 & 8 \\
30.12 .1980 & 10 & 5.2 & $7-8$ \\
06.05 .1982 & 20 & 5.8 & $7-8$ \\
15.02 .1984 & 20 & 5.1 & 6 \\
17.02 .1984 & 25 & 5.7 & 7 \\
19.03 .1984 & 15 & 7.2 & 9 \\
13.10 .1985 & 10 & 5.9 & 8 \\
27.04 .1985 & 10 & 5.1 & 7 \\
15.05 .1992 & 25 & 5.9 & $7-8$ \\
19.07 .2011 & 15 & 6.2 & 8 \\
24.05 .2013 & 18 & 5.6 & 7 \\
26.05 .2013 & 25 & 6.1 & 8 \\
29.09 .2017 & 5 & 5.1 & 6 \\
& & &
\end{tabular}




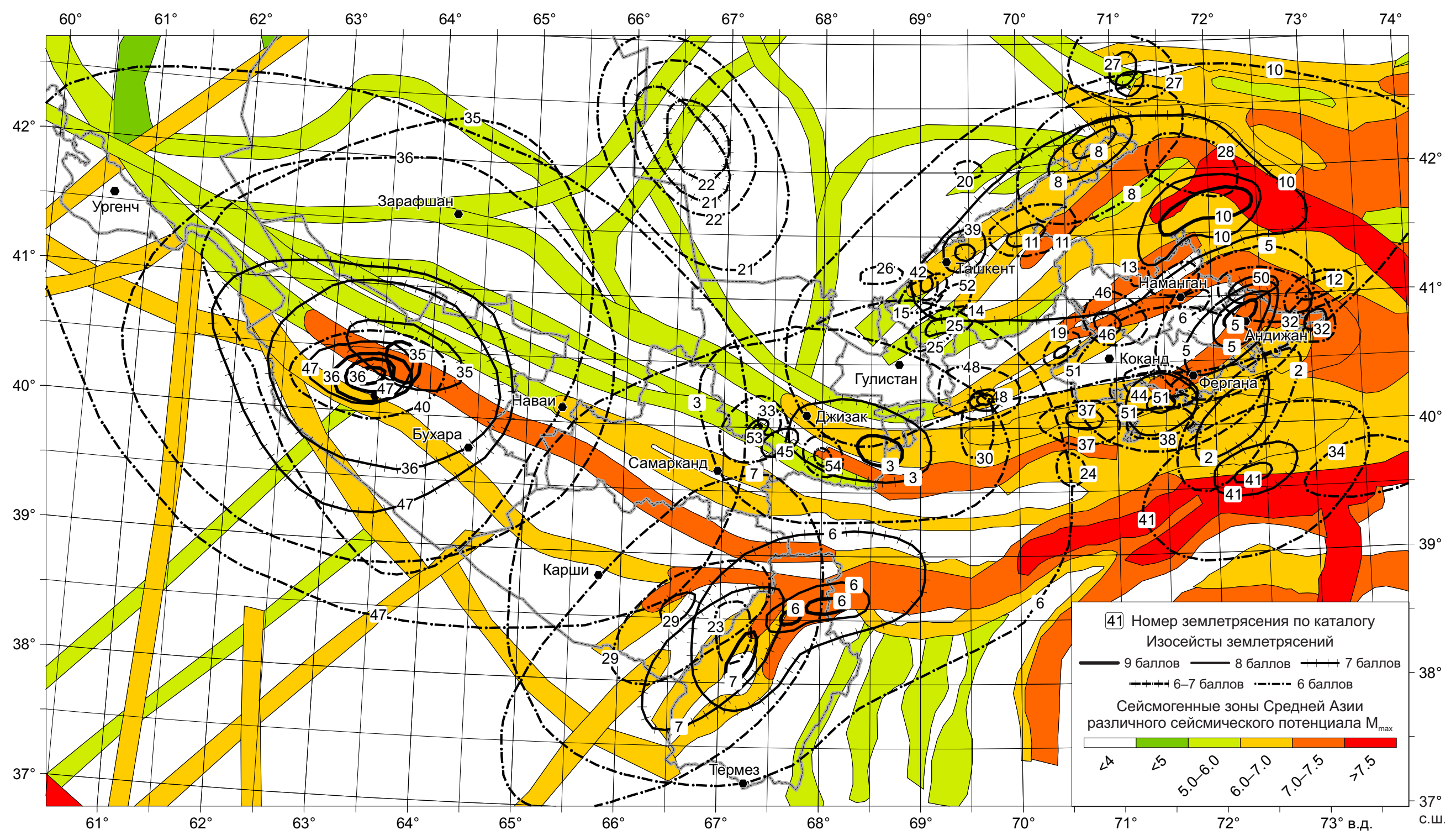

Рис. 2. Сводная схема изосейст сильных землетрясений территории Узбекистана и прилегающих территорий.

Fig. 2. Summary scheme of the isoseists of strong earthquakes that occurred in Uzbekistan and neighbouring areas. 


$$
\begin{gathered}
M_{L H}=1.34 m_{b}-1.89 ; \\
M_{L H}=0.9972 M_{s}-0.0057 .
\end{gathered}
$$

Изосейсты отдельного землетрясения, как правило, имеют эллипсовидную форму, что связано с различным характером распространения возмущения вдоль и вкрест тектонических структур, поэтому для каждого исследуемого землетрясения снимались размеры изосейст различной балльности по большой и малой оси эллипса, аппроксимирующего реальные изосейсты, а также размеры центрального радиуса. Вместе с тем для ряда землетрясений (Каратагское 1907 г., $M=7.3$; Чаткальское 1946 г., $M=7.5$, и др.) форма изосейст, в особенности младших, существенно отличалась от эллипсовидной. Для таких изосейст измерялся максимальный и минимальный размер замкнутой кривой, ограничивающей зоны различной макросейсмической балльности.

Экспериментальные данные о балльности сотрясений в эпицентре $I_{0}$ имелись для 122 сейсмических событий с магнитудой от 3.7 до 8.4. Исследовались различные формы связи между параметрами землетрясения и значением $I_{0}$. Значение балльности в эпицентре рассматривалось в виде функции магнитуды землетрясения $I_{0}=f(M)$, а также в виде функции магнитуды и глубины очага землетрясения $I_{0}=f(M, H)$. Зависимости затухания макросейсмической балльности с расстоянием для землетрясений различного энергетического уровня определялись уравнениями Блейка Шебалина и Ковеслигети, приведенными выше. Коэффициенты этих зависимостей определялись методом наименьших квадратов.

\section{3. РЕЗУЛЬТАТЫ И ИХ ОБСУЖДЕНИЕ 3.1. Балльность сотрясений в эпицентре землетрясения $\boldsymbol{I}_{\mathbf{0}}$}

На рис. 3 приведены экспериментальные значения балльности сотрясений в эпицентре для землетрясений с различной магнитудой. В результате линейной аппроксимации получена зависимость: $I_{0}=0.92 M+2.08$. Значение среднеквадратического отклонения такой аппроксимации составляет $\sigma=0.62$.

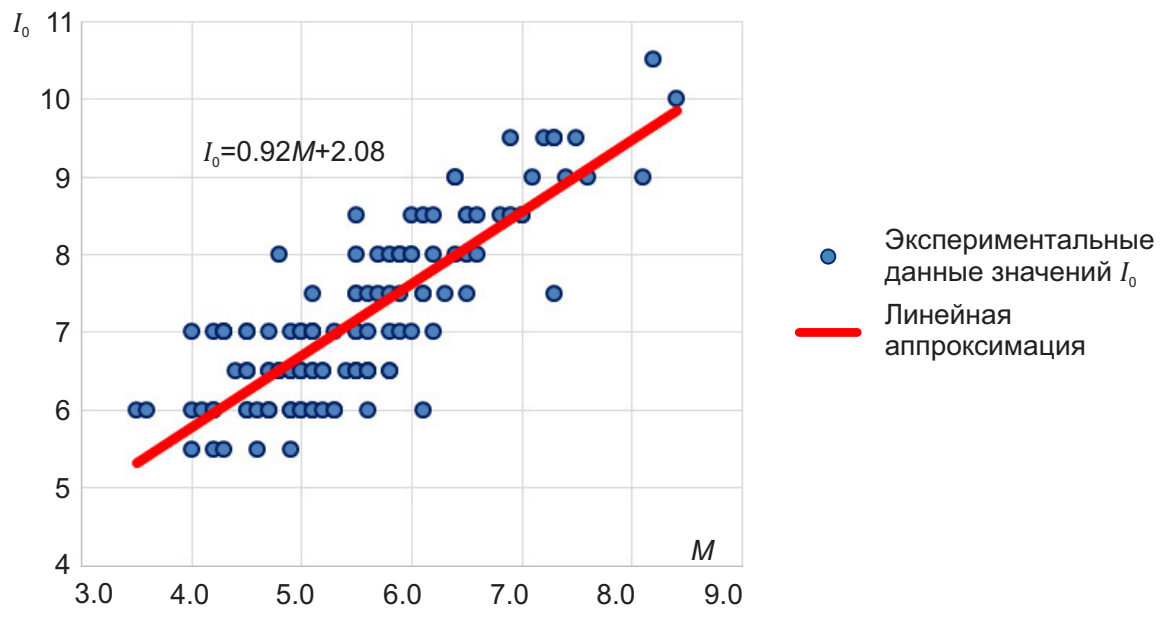

Рис. 3. Зависимость балльности сотрясения в эпицентре землетрясения $I_{0}$ от магнитуды $M$.

Fig. 3. Dependence of shaking intensity in earthquake source $I_{0}$ on earthquake magnitude $M$.

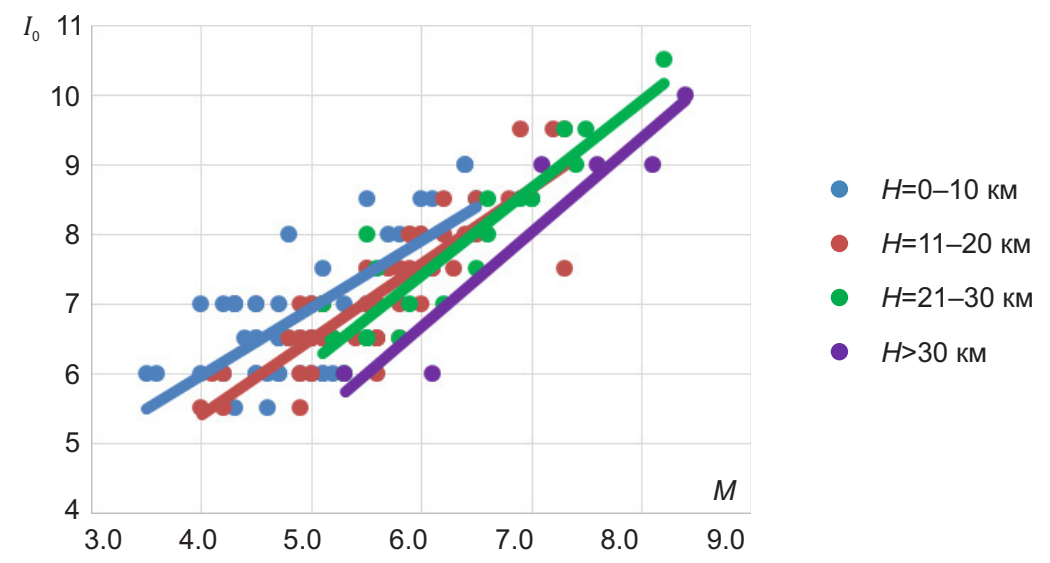

Рис. 4. Зависимость балльности сотрясения в эпицентре землетрясения $I_{0}$ от магнитуды землетрясения $M$ для различных глубин очагов землетрясений $H$.

Fig. 4. Dependence of shaking intensity in earthquake source $I_{0}$ on earthquake magnitude $M$ for various depths of earthquake sources $H$. 
На рис. 4 приведены зависимости $I_{0}=f(M)$, построенные по экспериментальным значениям $I_{0}$ для различных диапазонов глубин очагов землетрясений $Н$. Видно, что эти прямые практически параллельны. Это показывает, что скорость нарастания значения $I_{0}$ с увеличением магнитуды практически не зависит от выбранного диапазона глубин очагов землетрясений. Вместе с тем уровень этих графиков для различных диапазонов глубин очагов землетрясений разный. С увеличением глубины очага землетрясения уровень графиков понижается, т.е. для сейсмических событий с одинаковой магнитудой больший макросейсмический эффект в очаговой области наблюдается у землетрясений с меньшей глубиной очага. По всей совокупности экспериментальных данных получена следующая зависимость, связывающая балльность в эпицентре с магнитудой землетрясения и глубиной гипоцентра:

$$
I_{0}=1.14 M-1.28 \lg H+2.28(\sigma=0.57) .
$$

\section{2. Особенности затухания макросейсмической интенсивности с расстоянием}

Для всей территории Центральной Азии зависимость типа Блейка - Шебалина для распространения возмущения по среднему радиусу имеет вид:

$$
I=1.32 M-3.01 \lg R+3.55(\sigma=0.7) .
$$

Зависимость типа Ковеслигети, построенная по той же совокупности экспериментальных данных, дается выражением:

$$
I=1.33 M-2.37 \lg R-0.00205 R+2.24(\sigma=0.73) .
$$

На рис. 5 приведены кривые затухания макросейсмической интенсивности с расстоянием для землетрясений Центральной Азии с магнитудами $M=5.5-7.5$ по приведенным выше зависимостям типа Блейка - Шебалина и Ковеслигети. Построения сделаны для глубин очагов землетрясений $H=15$ км и $H=25$ км. Для сравнения на этом же рисунке показан характер затухания кривых по зависимости Н.В. Шебалина [Shebalin, 1968], построенной по мировым данным:

$$
I=1.5 M-3.5 \lg R+3 .
$$

Как это следует из рисунка, для рассматриваемого диапазона магнитуд и глубин очагов землетрясений зависимость типа Ковеслигети дает наименьшую интенсивность в ближней зоне, а авторская зависимость в форме уравнения Блейка - Шебалина дает наиболее высокие значения в дальней зоне. Расхождения в значениях макросейсмической интенсивности при различных законах затухания составляют порядка 0.5 балла в ближней зоне и 1.0 балла вдали от эпицентра землетрясения.

\section{3. Обобщенная зависимость затухания интенсивности сейсмических воздействий от расстояния с учетом глубин происходящих землетрясений}

Анализ экспериментальных данных показывает, что коэффициент затухания макросейсмической балльности с расстоянием существенно зависит от глубины очагов происходящих землетрясений. На рис. 6 приведены средние значения длины наблюденных изосейст различной макросейсмической балльности от землетрясений каждого магнитудного уровня (от $M=5.0$ до $M=7.5$ с градацией в полмагнитуды) для различных диапазонов глубин очагов землетрясений.

Практически во всем магнитудном диапазоне (кроме $M=7.0$, где статистика событий не очень большая) младшие изосейсты (I=4-6 баллов) для землетрясений с большей глубиной очага имеют большую протяженность, чем для землетрясений, очаг которых располагался ближе к дневной поверхности. Это означает, что затухание макросейсмической балльности с расстоянием у землетрясений с малой глубиной очага более быстрое, чем у глубоких землетрясений. Зависимости
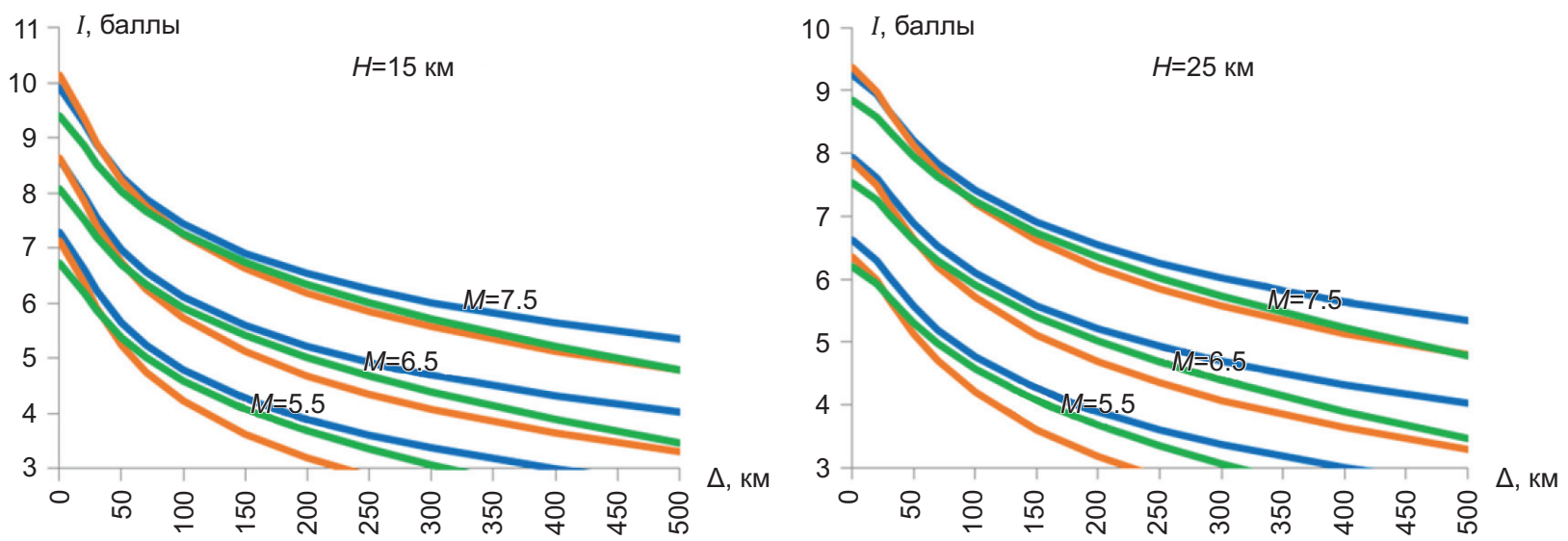

Авторская зависимость в форме Блейка - Шебалина
Авторская зависимость в форме Ковеслигети

Зависимость Н.В. Шебалина

Рис. 5. Сопоставление различных зависимостей затухания макросейсмической балльности от расстояния для землетрясений Центральной Азии.

Fig. 5. Comparison of various relations of macroseismic intensity attenuation with distance for earthquakes of the Central Asia. 
затухания макросейсмической интенсивности от расстояния типа Блейка - Шебалина и Ковеслигети данное обстоятельство не учитывают, поскольку входящий в них коэффициент затухания $b$ является величиной постоянной.

Попытки учета особенностей проявления сейсмических воздействий, обусловленных различной глубиной заложения очага землетрясения, описаны в ряде работ. Так, например, в работе Д. Бинди [Bindi et al., 2011] по территории Центральной Азии зависимость затухания макросейсмической интенсивности с расстоянием определяется уравнением:

$$
I=a_{1} M+a_{2}-a_{3} \lg \frac{R}{H}-a_{4}(R-H) \text {, где } R=\left(\Delta^{2}+H^{2}\right)^{1 / 2} .
$$

Для коэффициентов данной зависимости на основе макросейсмических данных по Центрально-Азиатскому региону методом наименьших квадратов получены следующие числовые значения: $a_{1}=0.898 ; a_{2}=1.215 ; a_{3}=1.809$; $a_{4}=3.447 \cdot 10^{-3}$.

Величина среднеквадратического отклонения в полученной зависимости составляет $\sigma=0.737$.

В данной работе связь между значением балльности в эпицентре и на различных гипоцентральных расстояниях $R$ от него рассматривалась в следующем виде:

$$
\frac{I-I_{0}}{\lg R-\lg H}=-(d M-e \lg H+f),
$$

где $I_{0}=a M-b \lg H+c, R=\left(\Delta^{2}+H^{2}\right)^{1 / 2}$.

С левой стороны данного равенства стоит отношение приращения балльности к приращению гипоцентрального расстояния, с правой - коэффициент затухания, т.е. предполагалось, что коэффициент затухания
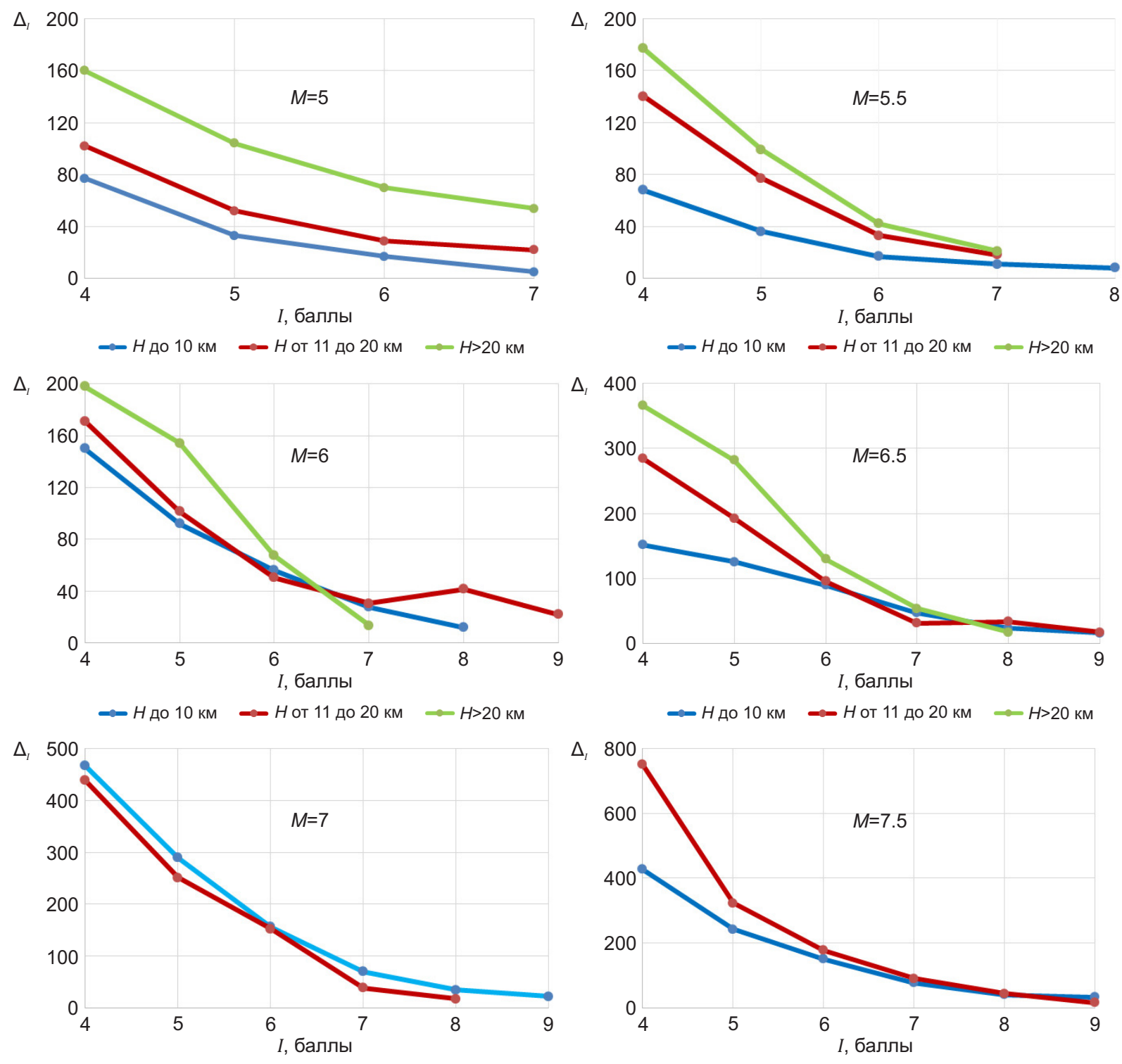

$\leadsto$ до 30 км $\rightleftharpoons$ - $>30$ км

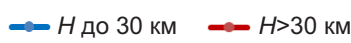

Рис. 6. Средние значения длины наблюденных изосейст различной макросейсмической балльности для различных диапазонов глубин землетрясений с магнитудой $M=5.0-7.5$.

Fig. 6. Average lengths of the real isoseists of macroseismic intensity for various ranges of earthquake depths $(M=5.0-7.5)$. 
интенсивности сейсмических воздействий с расстоянием зависит от магнитуды происходящего землетрясения $M$ и от его глубины $H$. Находя в данном выражении значение $I$, получаем:

$$
I=a M-b \lg H+c-d M \lg \frac{R}{H}+e \lg H \lg \frac{R}{H}-f \lg \frac{R}{H} .
$$

Коэффициенты зависимости определялись методом наименьших квадратов по макросейсмическим данным Центрально-Азиатского региона. В результате решения системы шести линейных уравнений с шестью неизвестными получена следующая зависимость затухания интенсивности сейсмических воздействий от расстояния по центральному радиусу:

$$
\begin{gathered}
I=1.475 M-2.646 \lg H+1.905-0.498 M \lg (R / H)+ \\
+1.159 \lg H \lg (R / H)-1.401 \lg (R / H) .
\end{gathered}
$$

Величина среднеквадратического отклонения в полученной зависимости составляет $\sigma=0.565$.

На рис. 7 показаны построенные по приведенной выше зависимости графики затухания макросейсми- ческой балльности с расстоянием для землетрясений с магнитудами $M=5.5, M=6.5$ и $M=7.5$, происходящих на различных глубинах, и аналогичные графики, полученные по зависимости Н.В. Шебалина.

Из приведенных рисунков видно, что как по авторской зависимости затухания, так и по зависимости Н.В. Шебалина, построенной по мировым данным, больший макросейсмический эффект в ближней зоне отмечается для землетрясений с малой глубиной очага, по сравнению с землетрясениями, происходящими на больших глубинах. Однако с удалением от источника характер затухания интенсивности сейсмических воздействий для сравниваемых зависимостей различен. В зависимости Н.В. Шебалина затухание макросейсмической балльности с расстоянием одинаковое для землетрясений с различной глубиной очага. По авторской зависимости уменьшение сейсмического эффекта с расстоянием для землетрясений с малой глубиной очага землетрясения происходит быстрее, чем у землетрясений с большей глубиной, что лучше согласуется с реальными эмпирическими фактами.

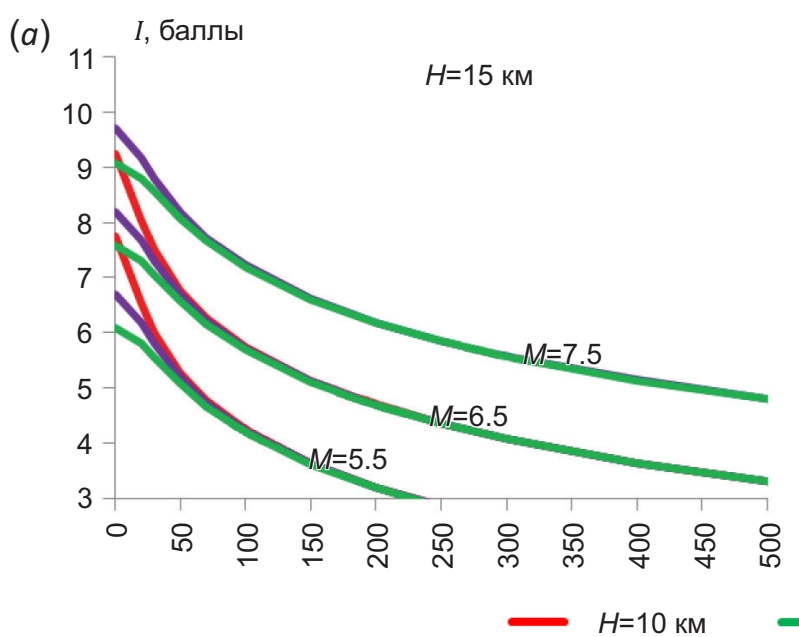

(б)

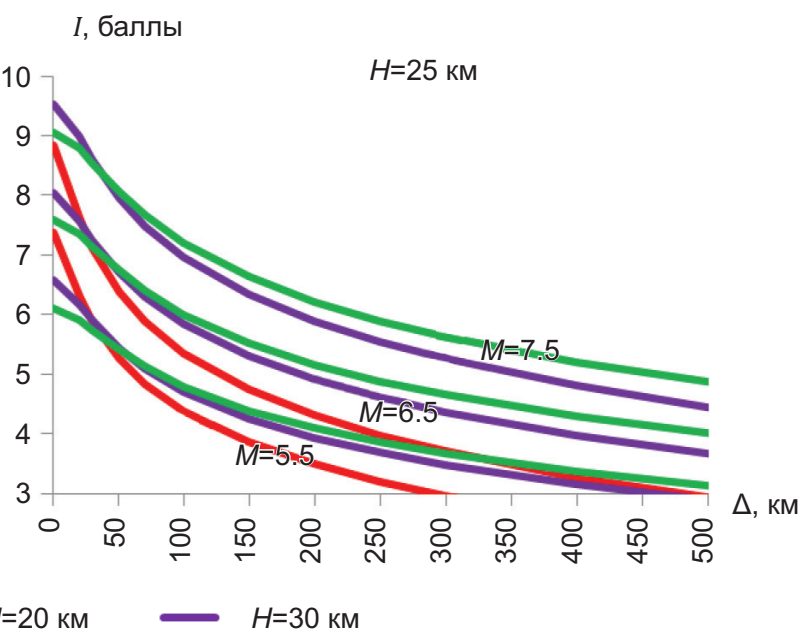

Рис. 7. Сопоставление характера затухания макросейсмической балльности с расстоянием по различным зависимостям: (a) - по зависимости Н.В. Шебалина; (б) - по авторской зависимости, с учетом зависимости коэффициента затухания от глубины очага.

Fig. 7. Macroseismic intensity attenuation with distance. Comparison with regard to dependences derived by: (a) - N.V. Shebalin; (б) authors, taking into account the dependence of attenuation coeficient on earthquake source depth.

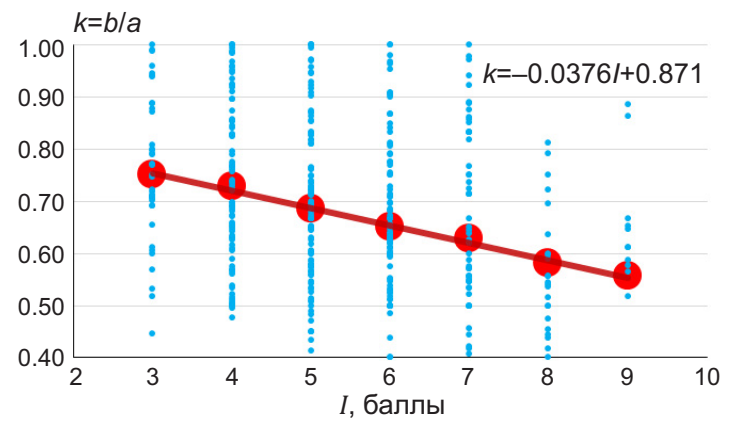

Средние значения коэффиициента сжатия для изосейст различной балльности

Коэффициенты сжатия для изосейст конкретных землетрясений

Зависимость коэфффициента сжатия эллипса $k$, аппроксимирующего изосейсты, от балльности

Рис. 8. Зависимость коэффициента сжатия эллипса $k$, аппроксимирующего изосейсты, от значения макросейсмического балла $I$.

Fig. 8. Dependence of ellipse compressibility coefficient $k$, approximating isoseists, on macroseismic intensity value $I$. 


\section{4. Учет эллиптичности изосейст}

В качестве параметра, характеризующего степень эллиптичности наблюденных изосейст, следуя работе [Mirzoev, Dzhuraev, 1985], рассматривался коэффициент сжатия эллипса $k$, равный отношению длины малой оси эллипса $b$ к длине большой оси $a(k=b / a)$. Были исследованы зависимости коэффициента сжатия эллипса, аппроксимирующего реальные изосейсты, от значения макросейсмического балла $I$, глубины очага $H$ и магнитуды $М$ землетрясения.

На рис. 8 приведена зависимость коэффициента сжатия эллипса $k$, аппроксимирующего изосейсты, от значения макросейсмического балла I. Здесь же показаны экспериментальные данные, по которым она построена. Видно, что разброс значений $k$ в пределах каждого значения балла достаточно велик $(\sigma=0.15-0.20)$. Вместе с тем для средних значений $k$ по каждому баллу уверенно выдерживается линейная зависимость:

$$
k=-0.0376 I+0.871 \text {. }
$$

На рис. 9 показана зависимость коэффициента сжатия эллипса $k$ от глубины $H$ очага землетрясения при фиксированном значении макросейсмического балла $I$. В отличие от работы [Mirzoev, Dzhuraev, 1985], где рассматривались данные только по территории Таджикистана, в нашем случае связь между этими параметрами оказалась невысокой. Соответствующие каждому баллу I коэффициенты корреляции $r$ между коэффициентом сжатия $k$ и глубиной очага землетрясения $H$ приведены на рис. 9.

Несколько лучший результат по средним значениям показывает связь между коэффициентом сжатия $k$ и магнитудой землетрясения $M$ (рис. 10). При достаточно большом разбросе данных для каждого значения макросейсмического балла наблюдается положительная корреляция между этими параметрами.

Методом наименьших квадратов получено следующее уравнение связи между коэффициентом сжатия эллипса $k$ и параметрами $I, M$ и $H$ :

$$
k=-0.05 I+0.002 H+0.04 M+0.73(\sigma=0.17) .
$$

Размеры круговых и эллиптических изосейст от землетрясений различного энергетического уровня, происходящих на различных глубинах, рассчитанные на основе авторской зависимости затухания макросейсмической балльности от расстояния (по центральному радиусу) и полученных выше соотношений между малой и большой осью эллипса, аппроксимирующего реальные изосейсты, приведены в табл. 2.

\section{4. ВЛИЯНИЕ ВЫБОРА ЗАКОНА ЗАТУХАНИЯ НА РЕЗУЛЬТИРУЮЩИЕ ОЦЕНКИ СЕЙСМИЧЕСКОЙ ОПАСНОСТИ}

Для оценки влияния выбора закона затухания макросейсмической балльности с расстоянием на результирующие оценки сейсмической опасности была построена
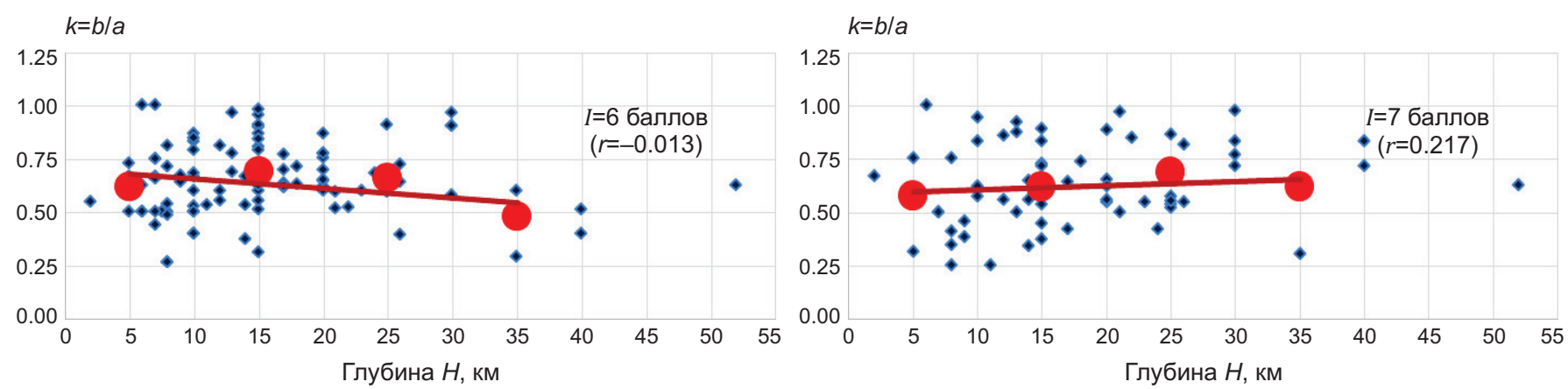

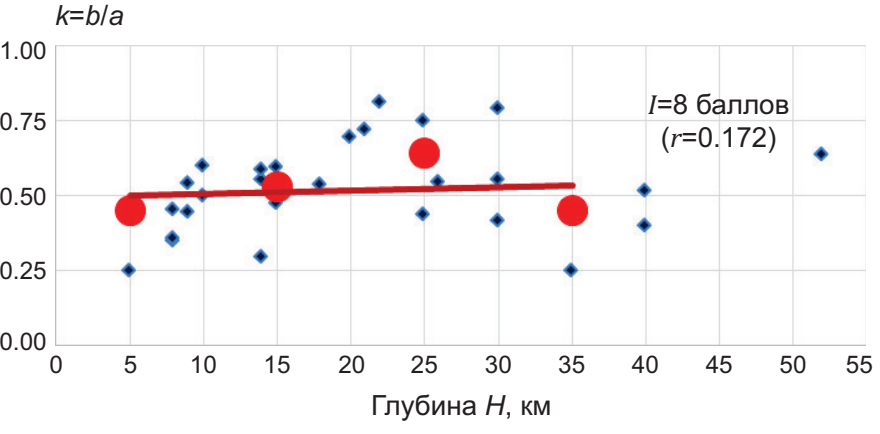

Экспериментальные значения коэффициента сжатия эллипса, аппроксимирующего изосейсты конкретных землетрясений

— Линия тренда

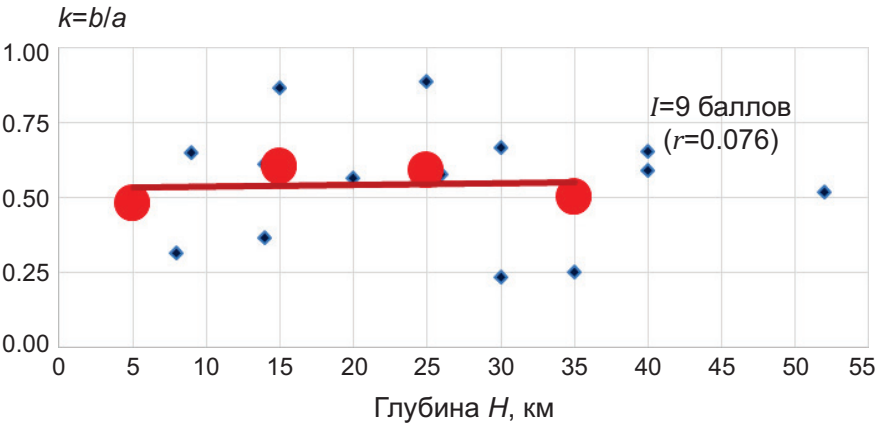

Средние значения коэффициента сжатия эллипса, - аппроксимирующего изосейсты, для землетрясений различных магнитуд

Рис. 9. Зависимость коэффициента сжатия эллипса $k$, аппроксимирующего изосейсты, от глубины очага землетрясения $H$ при фиксированном значении макросейсмического балла $I$.

Fig. 9. Dependence of ellipse compressibility coefficient $k$, approximating isoseists, on seismic source depth $H$ in case of fixed macroseismic intensity value $I$. 
серия карт сейсмического районирования территории Восточного Узбекистана, в которых при прочих равных входных параметрах, необходимых для расчета опасности, варьировался только закон затухания интенсивности сейсмических воздействий.

На рис. 11 приведена карта ощутимых и сильных землетрясений $(M \geq 4.3)$ территории Восточного Узбекистана с исторических времен. Большинство сильных землетрясений территории Узбекистана характеризуется взбросовым типом подвижки в очаге [Bezrodny, Tuychiev, 1987; Eksrom, Nettles, 2017]. На этой же карте показаны активные разломы земной коры и выделенные на их основе сейсмогенерирующие зоны [Ibragimov et al., 2002].

В качестве базовых карт, которые сопоставлялись между собой, рассматривались карты сейсмического районирования исследуемой территории в баллах макросейсмической шкалы MSK-64 для вероятности $P=0.98$ непревышения уровня сейсмического воздействия в течение 50 лет (период повторяемости сотрясений $T=2500$ лет). Эти карты были рассчитаны при следующих условиях:

- в качестве модели сейсмических источников рассматривались сейсмогенерирующие зоны территории Восточного Узбекистана и сопредельных с ним областей, выделение которых базируется на сейсмотектонических исследованиях разломов земной коры, активизированных на современном этапе геологического развития [Ibragimov et al., 2002];

- сейсмический потенциал $M_{\text {max }}$ сейсмогенерирующих зон оценивался комплексом сейсмотектонических [Ibragimov et al., 2002] и сейсмологических методов [Ibragimov et al., 2002; Artikov et al., 2012];

- параметры повторяемости землетрясений (сейсмическая активность $A_{10}$ и угловой коэффициент прямой $\gamma$ ) в зависимости Гутенберга - Рихтера в распределении
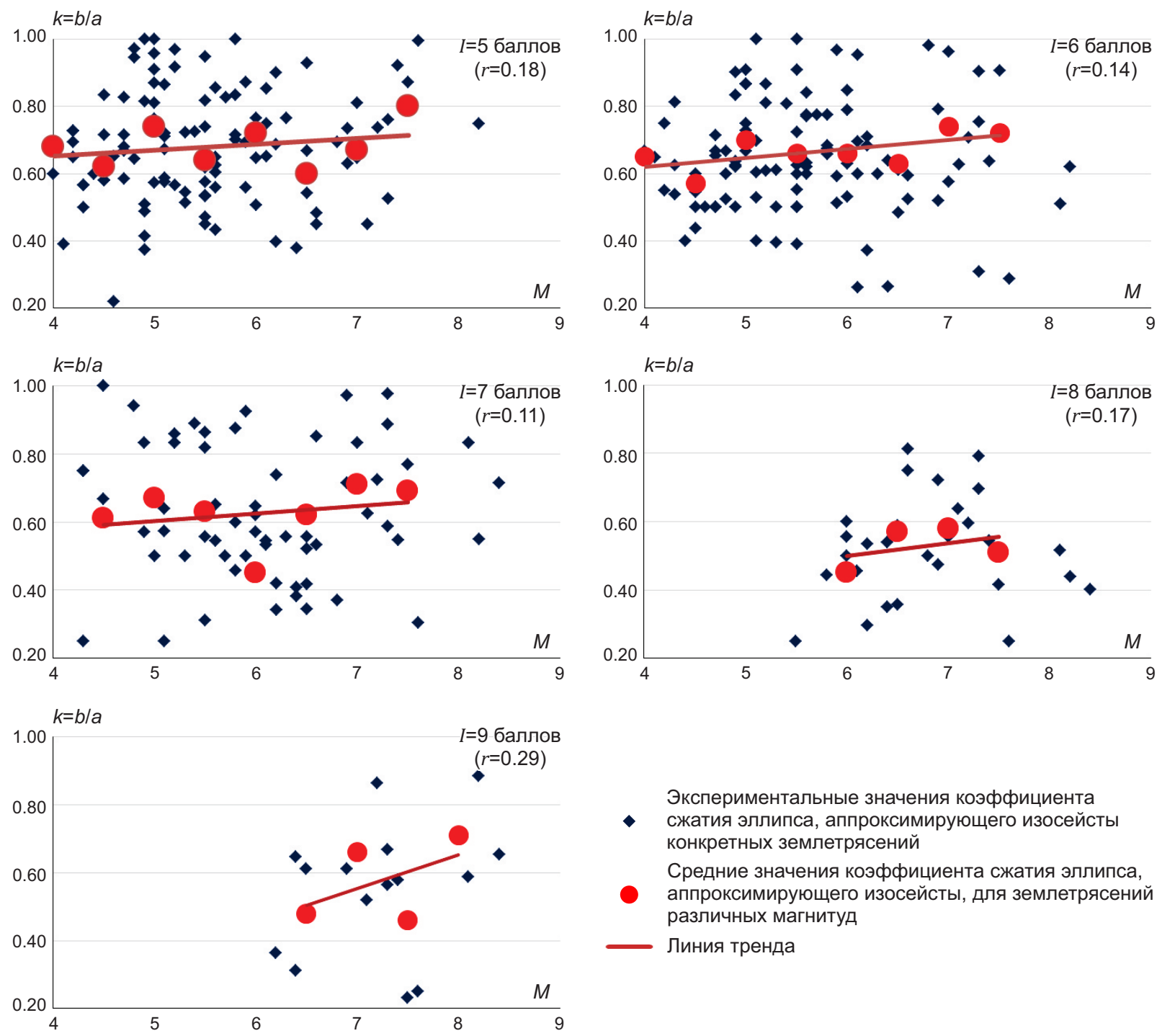

Экспериментальные значения коэффрициента

- сжатия эллипса, аппроксимирующего изосейсты конкретных землетрясений

Средние значения коэффициента сжатия эллипса

аппроксимирующего изосейсты, для землетрясений различных магнитуд

Линия тренда

Рис. 10. Зависимость коэффициента сжатия эллипса $k$, аппроксимирующего изосейсты, от магнитуды землетрясения $M$ при фиксированном значении макросейсмического балла $I$.

Fig. 10. Dependence of ellipse compressibility coefficient $k$, approximating isoseists, on earthquake magnitude $M$ in case of fixed macroseismic intensity value $I$. 
Таблица 2. Размеры круговых $\left(\Delta_{c^{\prime}}\right.$ км) и эллиптических $\left(\Delta_{a^{\prime}} \Delta_{b}\right.$, км) изосейст при землетрясениях различного магнитудного уровня $M$ и различной глубины $Н$ заложения гипоцентра

Table 2. Dimensions of circular $\left(\Delta_{c}, \mathrm{~km}\right)$ and elliptic $\left(\Delta_{a^{\prime}} \Delta_{b}, \mathrm{~km}\right)$ isoseists of earthquakes with different magnitudes $M$ and hypocenter depths $H$

\begin{tabular}{|c|c|c|c|c|c|c|c|c|c|c|}
\hline & & \multicolumn{3}{|c|}{$M=5$} & \multicolumn{3}{|c|}{$M=5.5$} & \multicolumn{3}{|c|}{$M=6.0$} \\
\hline & & $\Delta_{c}$ & $\Delta_{\mathrm{a}}$ & $\Delta_{\mathrm{b}}$ & $\Delta_{c}$ & $\Delta_{\mathrm{a}}$ & $\Delta_{\mathrm{b}}$ & $\Delta_{c}$ & $\Delta_{\mathrm{a}}$ & $\Delta_{\mathrm{b}}$ \\
\hline \multirow{4}{*}{$\stackrel{L}{\mathbb{1 1}}$} & $I=7$ & 4.8 & 6.6 & 3.9 & & & & & & \\
\hline & $I=6$ & 13.7 & 17.9 & 11.5 & & & & & & \\
\hline & $I=5$ & 30.3 & 37.8 & 26.1 & & & & & & \\
\hline & $I=4$ & 64.7 & 77.0 & 56.9 & & & & & & \\
\hline \multirow{5}{*}{$\stackrel{\circ}{\stackrel{ }{I}}$} & $I=8$ & & & & & & & 4.1 & 5.7 & 3.4 \\
\hline & $I=7$ & & & & 8.8 & 11.8 & 7.3 & 19.6 & 25.8 & 16.5 \\
\hline & $I=6$ & 13.8 & 17.9 & 11.7 & 27.1 & 34.4 & 23.0 & 43.8 & 54.6 & 37.7 \\
\hline & $I=5$ & 38.4 & 47.3 & 33.1 & 61.6 & 74.6 & 53.7 & 91.2 & 108.4 & 80.2 \\
\hline & $I=4$ & 91.5 & 107.9 & 80.9 & 134.8 & 156.3 & 120.3 & 186.9 & 213.1 & 168.4 \\
\hline \multirow{4}{*}{ 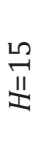 } & $I=7$ & & & & & & & 19.3 & 25.1 & 16.3 \\
\hline & $I=6$ & 9.0 & 11.5 & 7.6 & 28.0 & 35.2 & 24.0 & 50.2 & 61.9 & 43.3 \\
\hline & $I=5$ & 40.8 & 49.8 & 35.4 & 71.3 & 85.5 & 62.4 & 111.1 & 130.9 & 98.2 \\
\hline & $I=4$ & 107.0 & 125.1 & 95.1 & 166.2 & 191.1 & 149.1 & 239.4 & 271.0 & 216.8 \\
\hline \multirow{4}{*}{$\underset{\underset{N}{I I}}{\stackrel{\text { II }}{I}}$} & $I=7$ & & & & & & & 16.1 & 20.7 & 13.6 \\
\hline & $I=6$ & & & & 26.3 & 32.8 & 22.6 & 53.5 & 65.3 & 46.4 \\
\hline & $I=5$ & 40.2 & 48.7 & 35.0 & 76.8 & 91.2 & 67.5 & 125.4 & 146.5 & 111.4 \\
\hline & $I=4$ & 116.3 & 134.8 & 103.8 & 189.2 & 215.8 & 170.5 & 281.6 & 316.4 & 256.3 \\
\hline \multirow{4}{*}{$\stackrel{\text { L }}{\underset{N}{I}}$} & $I=7$ & & & & & & & 7.8 & 9.9 & 6.7 \\
\hline & $I=6$ & & & & 22.2 & 27.4 & 19.2 & 54.7 & 66.2 & 47.7 \\
\hline & $I=5$ & 37.5 & 45.0 & 32.8 & 79.6 & 93.8 & 70.3 & 135.9 & 157.5 & 121.3 \\
\hline & $I=4$ & 121.7 & 139.9 & 109.1 & 206.5 & 233.7 & 187.0 & 316.5 & 352.9 & 289.4 \\
\hline \multirow{5}{*}{ 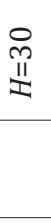 } & $I=6$ & & & & 14.4 & 17.6 & 12.5 & 54.4 & 65.3 & 47.6 \\
\hline & $I=5$ & 32.8 & 38.9 & 28.8 & 80.5 & 94.0 & 71.5 & 143.8 & 165.3 & 128.9 \\
\hline & $I=4$ & 124.2 & 141.7 & 112.0 & 219.7 & 246.8 & 199.9 & 345.8 & 382.8 & 317.8 \\
\hline & & & $l=6.5$ & & & $I=7.0$ & & & $=7.5$ & \\
\hline & & $\Delta_{c}$ & $\Delta_{\mathrm{a}}$ & $\Delta_{\mathrm{b}}$ & $\Delta_{c}$ & $\Delta_{\mathrm{a}}$ & $\Delta_{\mathrm{b}}$ & $\Delta_{c}$ & $\Delta_{\mathrm{a}}$ & $\Delta_{\mathrm{b}}$ \\
\hline \multirow{5}{*}{$\begin{array}{l}\stackrel{ }{1} \\
\underset{I}{I I}\end{array}$} & $I=8$ & 14.4 & 19.5 & 11.9 & & & & & & \\
\hline & $I=7$ & 32.4 & 41.6 & 27.5 & & & & & & \\
\hline & $I=6$ & 65.0 & 79.4 & 56.4 & & & & & & \\
\hline & $I=5$ & 127.1 & 148.6 & 112.9 & & & & & & \\
\hline & $I=4$ & 247.0 & 277.5 & 224.8 & & & & & & \\
\hline \multirow{6}{*}{$\stackrel{\text { L }}{\underset{7}{I I}}$} & $I=9$ & & & & 6.1 & 8.5 & 5.0 & 20.4 & 27.6 & 16.9 \\
\hline & $I=8$ & 12.6 & 16.9 & 10.5 & 27.3 & 35.8 & 22.9 & 44.1 & 56.6 & 37.3 \\
\hline & $I=7$ & 36.6 & 46.6 & 31.2 & 58.0 & 72.2 & 49.8 & 84.4 & 103.1 & 73.2 \\
\hline & $I=6$ & 78.6 & 95.1 & 68.5 & 114.1 & 135.6 & 100.3 & 157.0 & 183.5 & 139.5 \\
\hline & $I=5$ & 160.9 & 186.4 & 143.6 & 220.6 & 251.7 & 198.8 & 290.0 & 325.8 & 263.9 \\
\hline & $I=4$ & 326.0 & 363.6 & 298.1 & 424.8 & 467.0 & 392.3 & 534.5 & 579.6 & 498.5 \\
\hline \multirow{6}{*}{ 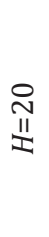 } & $I=9$ & & & & & & & 19.5 & 26.1 & 16.2 \\
\hline & $I=8$ & 5.5 & 7.3 & 4.6 & 27.7 & 36.0 & 23.4 & 48.7 & 61.9 & 41.4 \\
\hline & $I=7$ & 38.4 & 48.3 & 32.8 & 64.6 & 79.6 & 55.7 & 97.3 & 117.7 & 84.8 \\
\hline & $I=6$ & 88.1 & 105.7 & 77.1 & 132.1 & 155.7 & 116.8 & 186.3 & 215.9 & 166.2 \\
\hline & $I=5$ & 187.5 & 215.6 & 168.1 & 263.4 & 298.2 & 238.5 & 352.8 & 393.4 & 322.6 \\
\hline & $I=4$ & 393.0 & 435.1 & 361.1 & 521.8 & 569.7 & 484.2 & 666.3 & 717.8 & 624.5 \\
\hline \multirow{6}{*}{$\underset{\mathbb{N}}{\mathbb{N}}$} & $I=9$ & & & & & & & 16.2 & 21.5 & 13.6 \\
\hline & $I=8$ & & & & 26.4 & 33.9 & 22.4 & 51.6 & 64.9 & 44.2 \\
\hline & $I=7$ & 38.4 & 47.8 & 33.0 & 69.2 & 84.5 & 60.0 & 107.6 & 129.0 & 94.2 \\
\hline & $I=6$ & 95.0 & 112.9 & 83.6 & 146.7 & 171.5 & 130.3 & 211.2 & 242.8 & 189.4 \\
\hline & $I=5$ & 209.2 & 238.6 & 188.5 & 300.1 & 337.2 & 273.1 & 408.5 & 452.3 & 375.4 \\
\hline & $I=4$ & 451.2 & 496.0 & 416.6 & 608.9 & 660.4 & 567.9 & 787.5 & 842.9 & 741.8 \\
\hline \multirow{6}{*}{$\begin{array}{l}\text { II } \\
\underset{I}{I I}\end{array}$} & $I=9$ & & & & & & & 8.6 & 11.3 & 7.2 \\
\hline & $I=8$ & & & & 23.1 & 29.4 & 19.7 & 53.3 & 66.3 & 45.8 \\
\hline & $I=7$ & 36.8 & 45.4 & 31.8 & 72.2 & 87.4 & 62.9 & 116.0 & 137.9 & 102.0 \\
\hline & $I=6$ & 99.9 & 117.8 & 88.3 & 158.7 & 184.0 & 141.7 & 232.8 & 265.5 & 209.8 \\
\hline & $I=5$ & 227.2 & 257.2 & 205.8 & 332.3 & 370.6 & 303.9 & 458.8 & 504.4 & 423.7 \\
\hline & $I=4$ & 502.6 & 548.8 & 466.4 & 688.4 & 741.6 & 645.2 & 900.3 & 957.6 & 852.2 \\
\hline
\end{tabular}




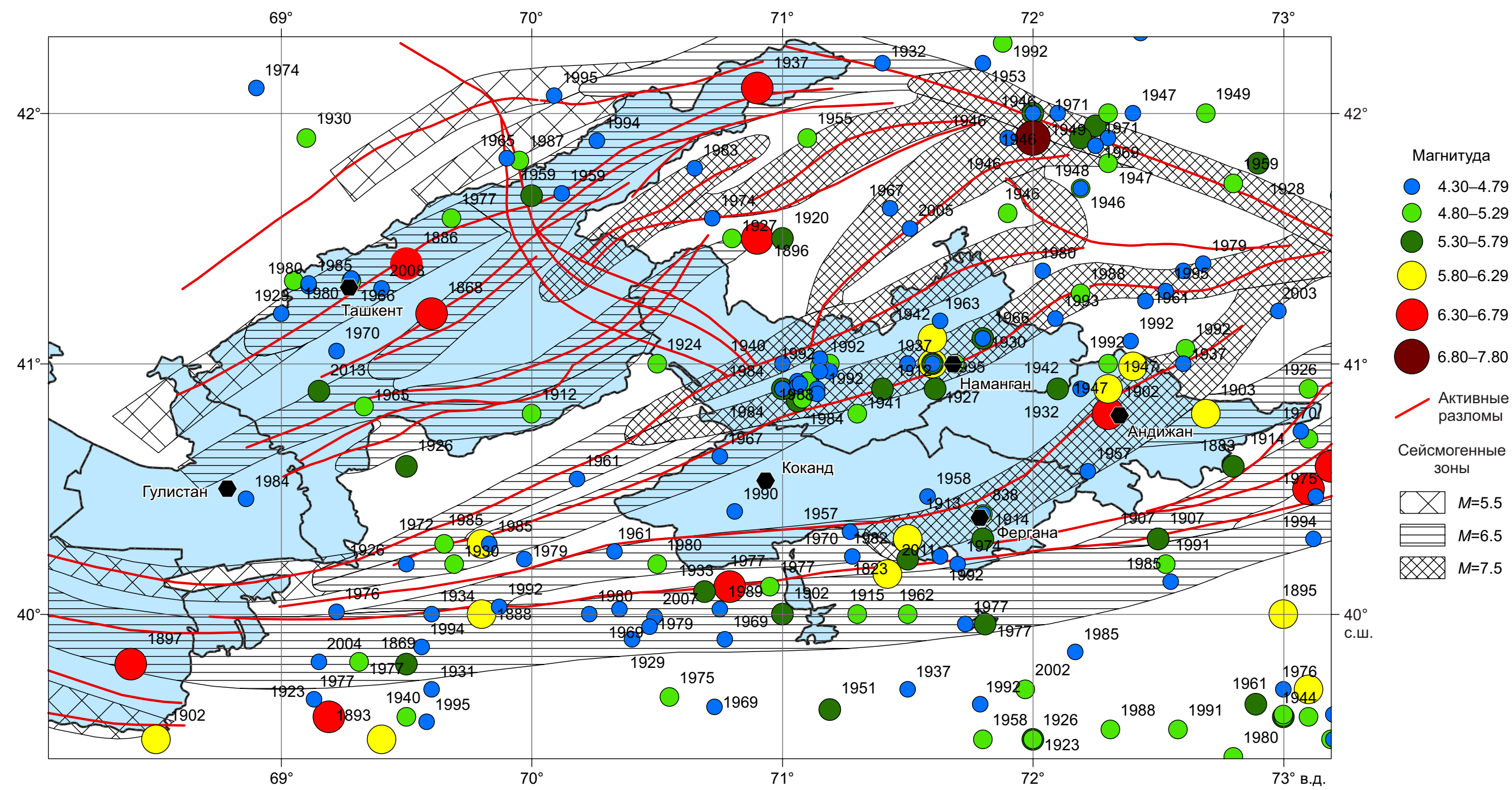

Рис. 11. Карта эпицентров ощутимых и сильных $(M \geq 4.3)$ землетрясений территории Восточного Узбекистана с исторических времен.

Fig. 11. Map showing the epicenters of notable and strong $(M \geq 4.3)$ earthquakes of East Uzbekistan in the historical timeline. 
сейсмических событий по энергетическим классам определены для каждой сейсмоактивной зоны [Artikov et al., 2012];

- в качестве глубин очагов землетрясений принималась наиболее вероятная для заданной магнитуды землетрясений глубина [Artikov et al., 2018];

- расчеты опасности проведены для землетрясений со взбросовым типом подвижки в очаге, поскольку, как отмечалось выше, именно он преобладает на исследуемой территории. В работе [Artikov et al., 2017] показано, что результирующие оценки сейсмической опасности для территории Восточного Узбекистана могут различаться на величину $\Delta I=0.3$ балла, если в законах затухания используется сдвиговый тип подвижки в очаге. При этом сейсмическая опасность выше при взбросах.

В качестве законов затухания макросейсмической балльности с расстоянием были рассмотрены четыре различные зависимости, обсуждавшиеся выше:

- зависимость Н.В. Шебалина по мировым данным, включая территорию Центральной Азии;
- зависимость типа Блейка - Шебалина, полученная по макросейсмическим данным Центральной Азии в рамках данного исследования;

- полученная по тем же данным зависимость типа Ковеслигети;

- авторская зависимость, в которой коэффициент затухания зависит от глубины очагов происходящих землетрясений.

Карты сейсмического районирования территории Восточного Узбекистана при рассмотренных выше законах затухания приведены на рис. 12, а-г.

Из рис. 12 видно, что области различной макросейсмической балльности на построенных картах существенно различаются. Вместе с тем, поскольку балл является величиной целочисленной, и выделение зон различной макросейсмической балльности связано с округлением рассчитанных значений интенсивности до целого числа, для сопоставляемых карт, в которых балльность отличается на единицу, реальные расхождения в оценках сейсмической опасности могут оказаться
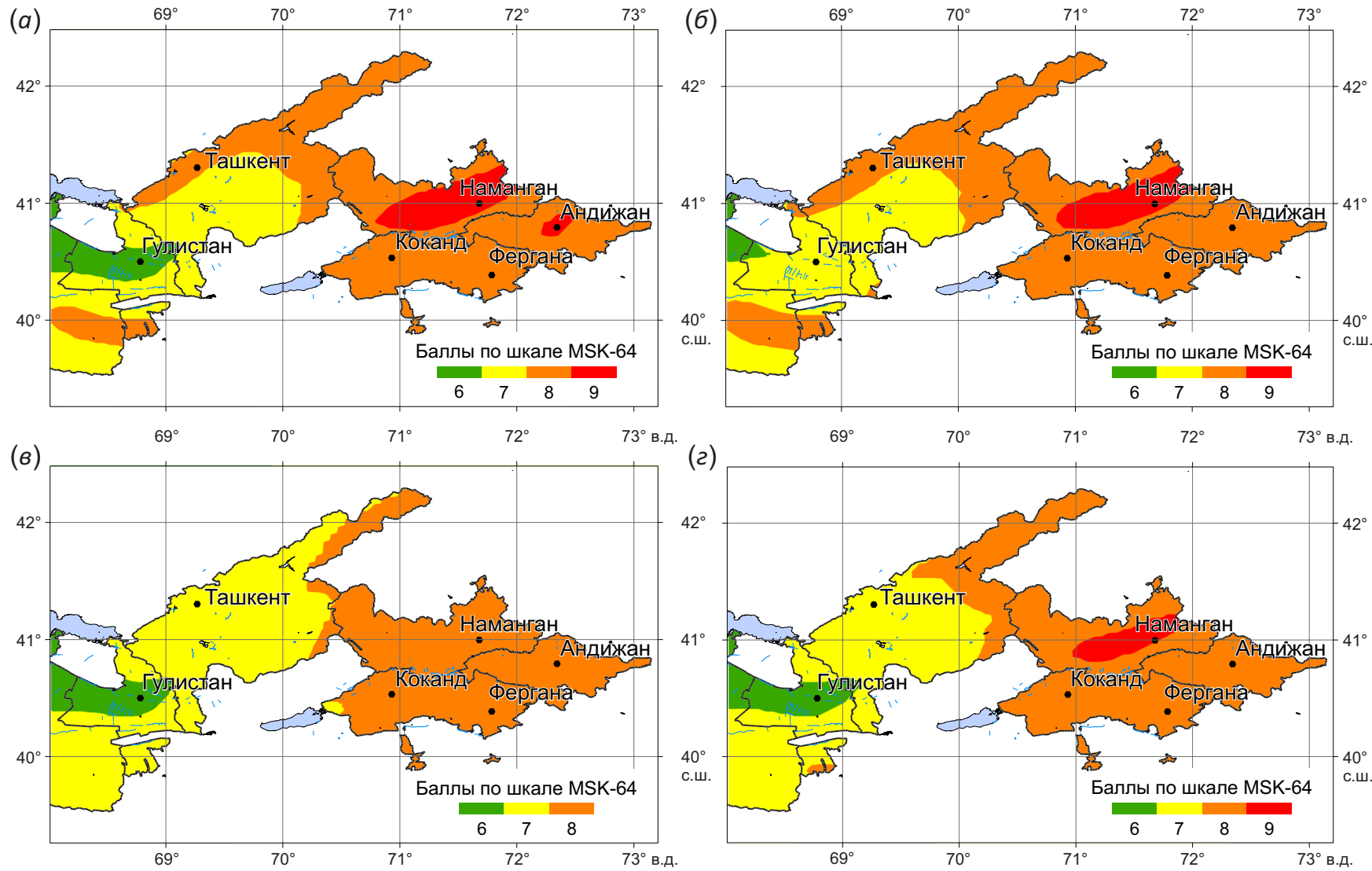

Рис. 12. Карты сейсмической опасности территории Восточного Узбекистана в баллах макросейсмической шкалы для вероятности $P=0.98$ непревышения уровня сейсмического воздействия в течение 50 лет при различных законах затухания интенсивности сейсмических воздействий с расстоянием.

(a) - зависимость Н.В. Шебалина по мировым данным; (б) - зависимость типа Блейка - Шебалина, полученная в данной работе; $(8)$ - зависимость типа Ковеслигети; (2) - авторская зависимость, в которой коэффициент затухания зависит от глубины очагов происходящих землетрясений.

Fig. 12. Seismic hazard map of East Uzbekistan in points of the macroseismic scale. $P=0.98$ - probability of not exceeding the seismic impact level for 50 years, using different laws of seismic load intensity attenuation with distance.

Dependences: ( $a$ ) - N.V. Shebalin (world data); (б) - Blake-Shebalin (this study); ( 8 ) - Covesligeti; ( 2 ) - authors, taking into account the dependence of attenuation coeficient on earthquake source depth. 
не столь значительными. Кроме того, равные приращения интенсивности сейсмических воздействий в различных диапазонах макросейсмической балльности могут давать существенную разницу в значениях максимальных ускорений колебаний грунта. Приращения макросейсмической интенсивности в областях с высокой балльностью дают бо́льшие приращения в значениях ускорений, чем те же самые приращения макросейсмической интенсивности в областях с низкой балльностью.

На рис. 13 приведены карты сейсмической опасности территории Восточного Узбекистана в значениях максимальных ускорений колебаний грунта, которые пересчитывались из карт макросейсмической балльности по зависимости Ф.Ф. Аптикаева [Aptikaev, 2012]:

$$
\lg a_{\max }=0.4 I-0.755 \pm 0.08 \text {. }
$$

Примем в качестве меры различия оценок опасности, вызванных выбором закона затухания, максимальную по площади разность $\Delta I$ для каждой пары из сопоставляемых карт, представленных на рис. 12. Чтобы отследить, в каком диапазоне макросейсмической балльности проявляются наибольшие отличия в сопоставляемых картах, наряду со значением $\Delta I$, при сопоставлении будем рассматривать разность в значениях максимальных ускорений $\Delta a_{\text {max }}$ Результаты количественного сопоставления карт сейсмической опасности, построенных при различных законах затухания, сведены в табл. 3.

Максимальная разность в оценках опасности на картах с различными законами затухания составляет $\Delta I=0.7$ балла, а значения максимальных ускорений разнятся на $\Delta a_{\max }=180 \mathrm{~cm} / \mathrm{c}^{2}$. Наибольшие значения оценок сейсмической опасности на территории Восточного Узбекистана получаются при выборе в качестве закона затухания зависимости Н.В. Шебалина, полученной на основе мировых данных, наименьшие - когда принимается зависимость типа Ковеслигети, построенная по макросейсмическим данным землетрясений Центральной Азии. По авторской зависимости затухания
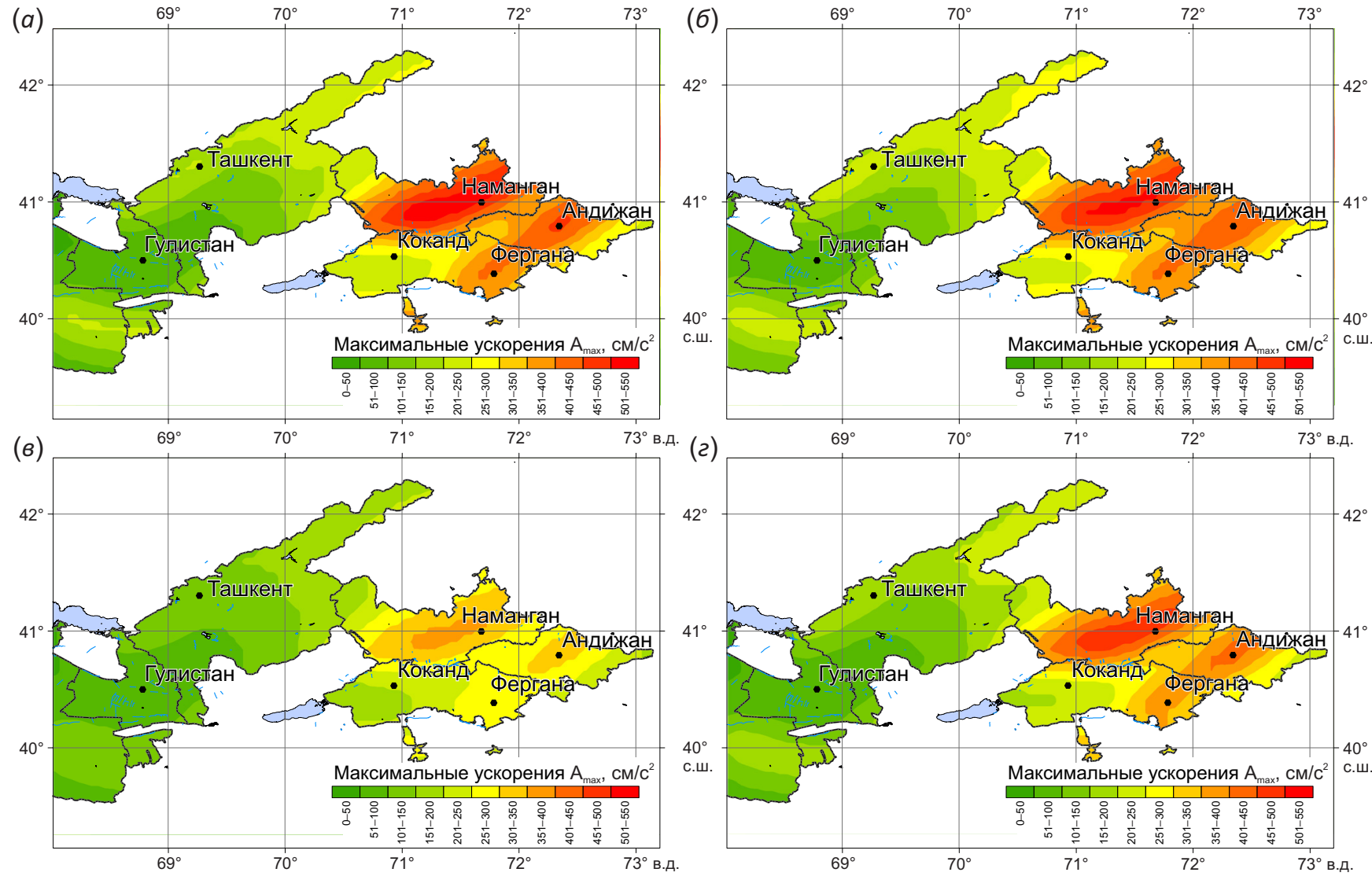

Рис. 13. Карты сейсмической опасности территории Восточного Узбекистана в значениях максимальных ускорений колебаний грунта для вероятности $P=0.98$ непревышения уровня сейсмического воздействия в течение 50 лет при различных законах затухания интенсивности сейсмических воздействий с расстоянием.

(a) - зависимость Н.В. Шебалина по мировым данным; (б) - зависимость типа Блейка - Шебалина, полученная в данной работе; $(8)$ - зависимость типа Ковеслигети; (2) - авторская зависимость, в которой коэффициент затухания зависит от глубины очагов происходящих землетрясений.

Fig. 13. Seismic hazard map of East Uzbekistan in values of maximum acceleration of ground tremor. $P=0.98-$ probability of not exceeding the seismic impact level for 50 years, using different laws of seismic load intensity attenuation with distance.

Dependences: ( $a$ ) - N.V. Shebalin (world data); (б) - Blake-Shebalin (this study); ( 8 ) - Covesligeti; ( 2 ) - authors, taking into account the dependence of attenuation coeficient on earthquake source depth. 
Таблица 3. Значения максимальных по площади разностей в оценках сейсмической опасности территории Восточного Узбекистана при различных законах затухания интенсивности сейсмических воздействий

Table 3. Values of maximum space differences in seismic hazard assessments for East Uzbekistan, using different laws of seismic load intensity attenuation

\begin{tabular}{|c|c|c|c|c|}
\hline $\begin{array}{l}\text { Зависимость Н.В. Шебалина по } \\
\text { мировым данным }\end{array}$ & & +0.4 балла +30 см/ $\mathrm{c}^{2}$ & +0.5 балла +180 см $/ \mathrm{c}^{2}$ & +0.4 балла +65 см/ $\mathrm{c}^{2}$ \\
\hline $\begin{array}{l}\text { Зависимость типа Блейка - } \\
\text { Шебалина по Центральной Азии }\end{array}$ & -0.4 балла -30 см/ $\mathrm{c}^{2}$ & & +0.7 балла +156 см $/ \mathrm{c}^{2}$ & +0.7 балла +54 cм/ $\mathrm{c}^{2}$ \\
\hline $\begin{array}{l}\text { Зависимость типа Ковеслигети } \\
\text { по Центральной Азии }\end{array}$ & -0.5 балла -180 см/ $\mathrm{c}^{2}$ & -0.7 балла -156 см $/ \mathrm{c}^{2}$ & & -0.3 балла -133 cм/ $/ \mathrm{c}^{2}$ \\
\hline $\begin{array}{l}\text { Авторская зависимость с учетом } \\
\text { глубины }\end{array}$ & -0.4 балла -65 см/ ${ }^{2}$ & -0.7 балла -54 см/ $\mathrm{c}^{2}$ & +0.3 балла +133 см/ $\mathrm{c}^{2}$ & \\
\hline
\end{tabular}

макросейсмической интенсивности с расстоянием, построенной с учетом глубины происходящих землетрясений, показатели сейсмической опасности оказались ниже, чем по зависимости типа Блейка - Шебалина на $\Delta I=0.7$ балла, а разница в значениях максимальныхускорений составила всего $\Delta a_{\max }=54 \mathrm{~cm} / \mathrm{c}^{2}$, что говорит о том, что эти зависимости существенно различаются при невысоких значениях макросейсмического балла. Оценки опасности, полученные по этой же зависимости и зависимости затухания в форме уравнения Ковеслигети, отличаются на $\Delta I=0.3$ балла, но значительная разница в величинах максимальных ускорений колебаний грунта $\Delta a_{\max }=133 \mathrm{~cm} / \mathrm{c}^{2}$ свидетельствует о том, что эти различия, напротив, наблюдаются при высоких значениях макросейсмической балльности.

\section{5. ЗАКЛЮЧЕНИЕ}

Результаты проведенных исследований сводятся к следующему.

1. На основе анализа макросейсмических данных землетрясений Центральной Азии получена региональная зависимость балльности сотрясений в эпицентре землетрясения от магнитуды и глубины очага. Построены зависимости затухания интенсивности сейсмических воздействий с расстоянием для землетрясений различного энергетического уровня в форме уравнений Блейка - Шебалина и Ковеслигети.

2. На экспериментальных данных показано, что коэффициент затухания макросейсмической интенсивности с расстоянием зависит от глубины происходящих землетрясений. Предложен новый тип зависимости затухания, учитывающий данный эффект, и методом наименьших квадратов определены ее коэффициенты. При единых экспериментальных данных величина среднеквадратического отклонения в полученной зависимости меньше, чем в зависимостях типа Блейка Шебалина и Ковеслигети.

3. Исследовано соотношение между малой и большой осью эллипса, аппроксимирующего реальные изосейсты, в зависимости от значения макросейсмического балла, магнитуды землетрясения и его глубины. Рассчитаны теоретические размеры круговых и эллиптических изосейст от землетрясений различного энергетического уровня, происходящих на различных глубинах.
4. На примере территории Восточного Узбекистана показано, что оценки сейсмической опасности существенно зависят от выбора вида закона затухания интенсивности сейсмических воздействий с расстоянием. Даже зависимости, построенные на одних и тех же экспериментальных данных, дают весьма значимые различия в результирующих оценках сейсмической опасности $(\Delta I=0.7$ балла).

\section{6. ЛИТЕРАТУРА/REFERENCES}

Aptikaev F.F., 2012. Instrumental Scale of Seismic Intensity. Science and Education, Moscow, 176 p. (in Russian) [АПтикаев Ф.Ф. Инструментальная шкала сейсмической интенсивности. М.: Наука и образование, 2012. 176 с.].

Artikov T.U., Ibragimov R.S., Ibragimova T.L., Mirzaev M.A., 2017. Research of Inaccuaracy of Modern Seismic Zoning Maps (on the Example of the East Uzbekistan Territory). Georisk 1, 36-44 (in Russian) [Артиков Т.У., Ибрагимов P.C., Ибрагимова Т.Л., Мирзаев М.А. Исследование погрешностей современных карт сейсмического районирования (на примере территории Восточного Узбекистана) // Геориск. 2017. № 1. С. 36-44].

Artikov T.U., Ibragimov R.S., Ibragimova T.L., Mirzaev M.A., 2018. Methodology for Constructing a New Set of Maps of General Seismic Zoning of the Territory of Uzbekistan OSR2017. Georisk 2, 6-24 (in Russian) [Артиков Т.У., Ибрагимов Р.С., Ибрагимова Т.Л., Мирзаев М.А. Методология построения нового комплекса карт общего сейсмического районирования территории Узбекистана ОСР2017 // Геориск. 2018. № 2. С. 6-24].

Artikov T.U., Ibragimov R.S., Ziyaudinov F.F., 2012. Seismic Hazard of the Uzbekistan Territory. Fan, Tashkent, 254 p. (in Russian) [Артиков Т.У., Ибрагимов Р.С., Зияудинов Ф.Ф. Сейсмическая опасность территории Узбекистана. Ташкент: Фан, 2012. 254 с.].

Artikov T.U., Sadykov F.S., Ibragimov R.S., Mirzaev M.A., 2014. Seismological Situation in the Focal Area of the Tuyabuguz Earthquake of May 25, 2013. In: Problems of Seismology in Uzbekistan. Institute of Seismology, Academy of Sciences of the Republic of Uzbekistan, Tashkent, 11, 3-9 (in Russian) [Артиков Т.У., Садыков Ф.С., Ибрагимов Р.С., Мирзаев М.А. Сейсмологическая обстановка в очаговой области Туябугузского землетрясения 25.05.2013 года // Проблемы сейсмологии в Узбекистане. Ташкент: ИС АН РУ, 2014. № 11. С. 3-9]. 
Bezrodny E.M., Tuychiev Kh.A., 1987. Focal Mechanisms of Strong Earthquakes in Uzbekistan. Fan, Tashkent, 143 p. (in Russian) [Безродный Е.M., Туйчиев Х.A. Механизмы очагов сильных землетрясений Узбекистана. Ташкент: Фан, 1987. 143 с.].

Bindi D., Parolai S., Oth A., Abdrakhmatov K., Muraliev A., Zschau J., 2011. Intensity Prediction Equations for Central Asia. Geophysical Journal International 187 (1), 327-337. https://doi.org/10.1111/j.1365-246X.2011.05142.x.

Chediya O.K., Dzhanuzakov K.D., Abdrakhmatov K.E., Ibragimov R.N., Sadykov Yu.S., Timush A.V., Nurmagambetov A.N., Turdukulov A.T., Negmatullaev S.Kh., Ishchuk A.R., 1995. Map of Seismogenic Zones in Central Asia. Scale 1:2500000 (in Russian) [Чедия О.К., Джанузаков К.Д., Абдрахматов К.Е., Ибрагимов Р.Н., Садыков Ю.С., Тимуш А.В., Нурмагамбетов А.Н., Турдукулов А.Т., Негматуллаев С.Х., Ищук А.Р. Карта сейсмогенерирующих зон Центральной Азии. Масштаб 1:2500000. 1995].

Danciu L., Giardini D., 2015. Global Seismic Hazard Assessment Program - GSHAP Legacy. Annals of Geophysics 58 (1), S0109. https://doi.org/10.3929/ethz-b-000100697.

Dzhanuzakov K.D., Il'yasov B.I., Knauf V.I., 1980. Kyrgyzstan. In: Seismic Zoning of the USSR Territory. Nauka, Moscow, 183-193 (in Russian) [Джанузаков К.Д., Ильясов Б.И., Кнауф В.И. Киргизия // Сейсмическое районирование территории СССР. М.: Наука, 1980. С. 183-193].

Dzhanuzakov K.D., Muraliev A.M., Sadykova K.A., Khalmurzaev A.S., 1997. Kochkor-Ata earthquake of May 15, 1992. In: Earthquakes of Northern Eurasia in 1992. UIPE RAS, Moscow, 45-47 (in Russian) [Джанузаков К.Д., Муралиев А.М., Садыкова К.А., Халмурзаев А.С. Кочкор-Атинское землетрясение 15 мая 1992 года // Землетрясения Северной Евразии в 1992 году. М.: ОИФЗ РАН, 1997. C. 45-47].

Eksrom G., Nettles M., 2017. Global CMT. Available from: http://www.globalcmt.org/ (Last Accessed 17.04.2014).

Ibragimov R.N., Nurmatov U.O., Ibragimov O.R., 2002. Seismotectonic Method for Assessing Seismic Hazard and Issues of Seismic Zoning. In: Seismic Zoning and Earthquake Forecasting in Uzbekistan. Hydroingeo, Tashkent, 59-74 (in Russian) [Ибрагимов Р.Н., Нурматов У.О., Ибрагимов О.Р. Сейсмотектонический метод оценки сейсмической опасности и вопросы сейсмического районирования // Сейсмическое районирование и прогноз землетрясений в Узбекистане. Ташкент: Гидроингео, 2002. С. 59-74].

Ismailov V.A., Nurmatov U.A., Ibragimov A.Kh., Khusomiddinov A.S., 2018. On Consequences of the Bakhmal Earthquake of September 29, 2017. Geology and Mineral Resources 1, 35-39 (in Russian) [Исмаилов В.А., Нурматов У.А., Ибрагимов А.Х., Хусомиддинов А.С. О последствиях Бахмальского землетрясения 29 сентября 2017 года // Геология и минеральные ресурсы. 2018. № 1. С. 35-39].

Kovesligethy R., 1907. Seismischer Starkegral und Intensität der Beben. Gerlands Beiträge zur Geophysik 8, 22-29.

Mirzoev K.M., Dzhuraev R.U., 1985. The Main Regularities of Attenuation of Earthquake Magnitudes in the Territory of Tajikistan. In: Earthquakes of Central Asia and Kazakhstan. 1983. Donish Publishing House, Dushanbe, 99-128 (in Russian) [Мирзоев К.М., Джураев Р.У. Основные закономерности затухания балльности землетрясений на территории Таджикистана // Землетрясения Средней Азии и Казахстана. 1983. Душанбе: Изд-во «Дониш», 1985. C. 99-128].

Mukambaev A.S., Mikhailova N.N., 2014. Solution of the Problem of Inhomogeneity of Magnitudes in Seismic Sounding Studies of the Republic of Kazakhstan Territory. Bulletin of NNC RK 4 (60), 86-92 (in Russian) [Мукамбаев А.С., Михайлова Н.Н. Решение проблемы неоднородности магнитуд в работах по сейсмическому зондированию территории Республики Казахстан // Вестник НЯЦ РК. 2014. Вып. 4. С. 86-92].

New Catalog of Strong Earthquakes in the USSR from Ancient Times to 1975,1977 . Nauka, Moscow, 536 p. (in Russian) [Новый каталог сильных землетрясений на территории СССР с древнейших времен до 1975 года. М.: Наука, 1977. 536 с.]

Rautian T.G., 1960. Energy of Earthquakes. In: Methods of Detailed Study of Seismicity. Publishing House of the USSR Academy of Science, Moscow, 176, 75-114 (in Russian) [Payтиан Т.Г. Энергия землетрясений // Методы детального изучения сейсмичности. М.: Изд-во АН СССР, 1960. № 176. С. 75-114].

Rautian T.G., Khalturin V.I., Fujita K., Mackey K.G., Kendall A.D., 2007. Origins and Methodology of the Russian Energy K-Class System and Its Relationship to Magnitude Scales. Seismological Research Letters 78 (6), 579-590. https://doi.org/10.1785/gssrl.78.6.579.

Riznichenko Yu.V., 1985. Problems of Seismology. Selected Works. Nauka, Moscow, 408 p. (in Russian) [Ризниченко Ю.В. Проблемы сейсмологии. Избранные труды. М: Наука, 1985. 408 с.].

Sadykov A., 2004. Seismic Regime of the Kazakhstan Territory. Gylym Publishing House, Almaty, 270 p. (in Russian) [Садыков А. Сейсмический режим территории Казахстана. Алматы: Изд-во Гылым, 2004. 270 с.].

Seiduzova S.S., 1990. Mathematical Modeling of Macroseismic Intensity Field. In: Seismicity of the Uzbekistan Territory. Fan, Tashkent, 154-183 (in Russian) [Сейдузова C.C. Математическое моделирование поля макросейсмической интенсивности //Сейсмичность территории Узбекистана. Ташкент: Фан, 1990. С. 154-183].

Shebalin N.V., 1968. Methods to use engineering and seismological data for seismic zoning. In: Seismic Zoning of the USSR. Nauka, Moscow, p. 95-111 (in Russian) [Шебалин Н.В. Методы использования инженерно-сейсмологических данных при сейсмическом районировании // Сейсмическое районирование СССР. М.: Наука, 1968. C. 95-111].

Shebalin N.V., 1972. Macroseismic Data as Information on Source Parameters of Large Earthquakes. Physics of the Earth and Planetary Interiors 6 (4), 316-323. https://doi. org/10.1016/0031-9201(72)90016-7.

Tatevosyan R.E., 2013. Macroseismic Studies. Science and Education, Moscow, 384 p. (in Russian) [Татевосян P.Э. Макросейсмические исследования. М.: Наука и образование, 2013. 384 с.]. 
Ulomov V.I., Bogdanov M.I., Trifonov V.G., Gusev A.A., Gusev G.S., Akaktova K.N., Aptikaev F.F., Danilova T.I., Kozhurin A.I., Medvedeva N.S., Nikonov A.A., Peretokin S.A., Pustovitenko B.G., Strom A.L., 2016. Explanatory Note to the Set of Maps of General Seismic Zoning of the Russian Federation Territory OSR-2016. Engineering Surveys 7, 49-122 (in Russian) [Уломов В.И., Богданов М.И., Трифонов В.Г., Гусев А.А., Гусев Г.С., Акактова К.Н., Аптикаев Ф.Ф., Данилова Т.И., Кожурин А.И., Медведева Н.С., Никонов А.А., Перетокин С.А., Пустовитенко Б.Г., Стром А.Л. Пояснительная записка к комплекту карт общего сейсмического районирования территории Российской Федерации ОСР2016 //Инженерные изыскания. 2016. № 7. С. 49-122].

Usmanova M.T., Nurmatov U.A., Dzhuraev A., Zahidov T.K., Yusupdzhanova U.A., Yodgorov Sh.I., Dzhuraev O.A., Hafizov U.A,
2015. Marzhanbulak Earthquake of May 26, 2013. Geology and Mineral Resources 2, 29-35 (in Russian) [Усманова М.T., Нурматов У.А., Джураев А., Захидов Т.К., Юсупджанова У.А., Ёдгоров Ш.И., Джураев О.А., Хафизов У.А. Маржанбулакское землетрясение 26 мая 2013 г. // Геология и минеральные ресурсы, 2015. № 2. С. 29-35].

Ziyaudinov F.F., Dzhuraev A., Dzhuraev N.M., Usmanova M.T., Nurmatov U.A., Artikov T.U., 2012. Kansk Earthquake on July 20, 2011. In: Problems of Seismology in Uzbekistan. Institute of Seismology, Academy of Sciences of the Republic of Uzbekistan, Tashkent 9, 3-8 (in Russian) [Зияудинов Ф.Ф., Джураев А., Джураев Н.М., Усманова М.Т., Нурматов У.А., Артиков Т.У. Канское землетрясение 20 июля 2011 года // Проблемы сейсмологии в Узбекистане. Ташкент: ИС АН РУз, 2012. № 9. С. 3-8]. 